\title{
Chapter 23 \\ Bivalve Aquaculture Carrying Capacity: Concepts and Assessment Tools
}

\author{
Aad C. Smaal and L. A. van Duren
}

\begin{abstract}
The carrying capacity concept for bivalve aquaculture is used to assess production potential of culture areas, and to address possible effects of the culture for the environment and for other users. Production potential is depending on physical and production carrying capacity of the ecosystem, while ecological and social carrying capacity determine to what extent the production capacity can be realized. According to current definitions, the ecological carrying capacity is the stocking or farm density of the exploited population above which unacceptable environmental impacts become apparent, and the social capacity is the level of farm development above which unacceptable social impacts are manifested. It can be disputed to what extent social and ecological capacities differ, as unacceptable impacts are social constructs. In the approach of carrying capacity, focus is often on avoiding adverse impacts of bivalve aquaculture. However, bivalve populations also have positive impacts on the ecosystem, such as stimulation of primary production through filtration and nutrient regeneration. These ecosystem services deserve more attention in proper estimation of carrying capacity and therefore we focus on both positive and negative feedbacks by the bivalves on the ecosystem. We review tools that are available to quantify carrying capacity. This varies from simple indices to complex models. We present case studies of the use of clearance and grazing ratio's as simple carrying capacity indices. Applications depend on specific management questions in the respective areas, the availability of data and the type of decisions that need to be made.

For making decisions on bivalve aquaculture, standards, threshold values or levels of acceptable change (LAC) are used. The FAO framework for aquaculture is formulated as The Ecosystem Approach to Aquaculture. It implies stakeholder
\end{abstract}

\footnotetext{
A. C. Smaal $(\bowtie)$

Wageningen UR - Wageningen Marine Research (WMR), Yerseke, The Netherlands

Department of Aquaculture and Fisheries, Wageningen University, Wageningen,

The Netherlands

e-mail: aad.smaal@wur.nl

L. A. van Duren

Deltares, Delft, The Netherlands

e-mail: luca.vanduren@deltares.nl
} 
involvement, and a carrying capacity management where commercial stocks attribute in a balanced way to production, ecological and social goals. Simulation models are being developed as tools to predict the integrated effect of various levels of bivalve aquaculture for specific management goals, such as improved ecosystem resilience. In practice, bivalve aquaculture management is confronted with different competing stocks of cultured, wild, restoration and invasive origin. Scenario models have been reviewed that are used for finding the balance between maximizing production capacity and optimizing ecological carrying capacity in areas with bivalve aquaculture.

\begin{abstract}
Chinese 双壳贝类水产养殖容量的概念往往用于养殖区生产潜力 的评估, 并确定养殖对环境和其他区域使用者的潜在影响。生产潜力取决于 生态系统的物理状态和养殖容量, 而生态和社会容量则决定生产能力的实现 程度。根据目前的定义, 生态容量是指对养殖水域生态系统产生不良生态影 响的最小养殖密度, 社会容量是指不引起负面社会影响的最大养殖密度或规 模。由于这种不可接受影响的评定往往基于社会主观因素, 对社会容量和生 态容量认知的差异程度因人而异。在容量评估方法方面, 我们通常更关注如 何避免贝类养殖对环境造成不可逆的负面影响。但是双壳贝类群体对生态系 统同样存在正面的影响, 它们可以通过滤食过程和营养物质释放来提高生态 系统的初级生产力。双壳贝类的生态系统服务功能使我们在进行容量评估时 需要同时考虑正负两方面的效应。本篇总结了一些容量评估的量化工具, 其 中包括简单的参数指标和复杂的生态模型。我们列举了一些利用滤水率和摄 食率作为简单容量估算指标的案例研究。容量评估工具的应用取决于养殖区 域面临的具体问题, 具体环境, 数据的可用性以及需要作出的规划类型。

为了制定双壳贝类关于养殖标准, 养殖对环境影响限值或可接受程度的相 关规划 (LAC), 联合国粮农组织制定了水产养殖框架(The Ecosystem Approach to Aquaculture, 水产养殖的生态系统方法), 这意味着在制定决策时需要考虑 生产效益, 生态效益和社会效益三者兼顾的容量管理。各种生态模型正在发 展为预测不同水平的贝类养殖对既定管理目标 (如改善生态系统弹性等) 综合 影响的评估工具。

在实际生产过程中, 双壳贝类的养殖管理面临着不同的养殖种群, 野生种 群, 恢复种群和入侵种竞争的局面。针对上述的不同场景, 可以应用生态系统 模型对双壳贝类养殖的最大生产力和生态容量之间平衡点的进行研究。
\end{abstract}

Keywords Production carrying capacity $\cdot$ Ecological carrying capacity $\cdot$ Social carrying capacity $\cdot$ Indicators $\cdot$ Indices $\cdot$ Models

关键词 生产容量 - 生态容量 - 社会容量 - 指示物 - 指标 - 模型 


\subsection{Introduction}

Marine bivalves are usually cultivated under natural conditions in open water systems and depend on feed, seed and space available in the natural ecosystem. Hence it is an extractive form of aquaculture, using resources supplied by the local ecosystem, and closely linked to natural processes. There are many interactions between the bivalves and their environment. High density bivalve populations filter large quantities of water, take up phytoplankton, reduce turbidity, excrete dissolved nutrients, and produce biodeposits. Under nutrient limited conditions, nutrient regeneration may stimulate primary production, providing a positive feedback on phytoplankton availability for the bivalves. If bivalve stocks are too large, filtration may be larger than the total system can sustain (i.e. the rate of primary production plus the rate of import of food into the system). This incurs phytoplankton depletion, being a negative feedback on food availability. As shown in Jansen et al. (2019, this volume), the balance of positive and negative feedbacks between the bivalves and their food determines the provisioning services of bivalve aquaculture. This also depends on the interaction between cultivated and wild bivalve stocks (Newell 2004). If expansion of bivalve aquaculture stimulates nutrient regeneration and primary production, the impact is positive for all filter feeder stocks. If bivalve culture expansion implies a total stock size that leads to phytoplankton depletion, it has negative impacts for the ecosystem as well as for bivalve aquaculture. So, knowledge of the feedback processes is needed as a basis for addressing sustainable bivalve aquaculture production, and to establish the optimum cultivated stock size. Recent reviews have been published on bivalve carrying capacity studies (McKindsey 2013; Filgueira et al. 2015). These reviews analyse carrying capacity in the framework of the ecosystem approach to aquaculture (EAA) that means: (i) to be developed in the context of ecosystem functions and services with no degradation beyond the resilience capacity, (ii) to improve human well-being and equity for all relevant stakeholders, and (iii) to be developed in the context of other relevant sectors. Critical in this approach is the involvement of stakeholders (Soto et al. 2008; see also Byron et al. 2011a).

McKindsey 2013, presents an overview of the various impacts of bivalve aquaculture, as a basis for addressing the different types of carrying capacity, and how these can be used in decision making processes. Filgueira et al. 2015, also review the bivalve aquaculture impacts, and tools like models and indices to address the links between the different carrying capacity types, with a focus on ecological and social carrying capacities.

Our paper is based on these reviews, as a basis for addressing adverse ecosystem impacts as well as ecosystem services provided by bivalve aquaculture culture. The approach in this review is focused on a scale that is larger than the farm scale. The effects of bivalve aquaculture, including positive and negative feedbacks on the ecosystem's carrying capacity, require integration of farm scale impacts on the surrounding environment (watershed). This review therefore focusses on the scale of an entire bay/watershed. 
We have analysed case studies where the role of various filter feeder stocks have been taken into account: culture stocks, wild stocks, and stocks of introduced invasive populations, as a basis for understanding factors that determine bivalve carrying capacity and for developing tools for ecosystem based management.

\subsubsection{Concepts}

The carrying capacity concept originally comes from the logistic population growth curve, that reaches the asymptote $\mathrm{K}$ when the population size is at maximum. This growth curve shows maximum growth rate at half the carrying capacity. So, maximum yield, either in fisheries or in aquaculture, is achieved at a population size that corresponds with half the $\mathrm{K}$ value in the logistic function (Odum 1953; Kashiwai 1995). This shows the difference between the carrying capacity concept for aquaculture versus carrying capacity for natural populations: in contrast to natural populations, carrying capacity for exploitation is maximized at a population size that is typically not at maximum size (Smaal et al. 1998). Rather than a population parameter, the carrying capacity concept can also be considered as a characteristic of the ecosystem: Dame and Prins 1998 define bivalve carrying capacity as the total bivalve biomass supported by a given ecosystem as a function of the water residence time, primary production time and bivalve clearance time. They show that carrying capacity for bivalve exploitation depends primarily on the availability of food through transport and primary production - in relation to filter feeding capacities.

Inglis et al. 2000, proposed a distinction in physical, production, ecological and social carrying capacity. Physical carrying capacity defines the total area of farms that can be accommodated in a given space; the production capacity is defined as the standing stock at which the annual production of the marketable cohort is maximised. The ecological carrying capacity is the stocking or farm density of the exploited population above which unacceptable environmental impacts become apparent, and the social capacity is the level of farm development above which unacceptable social impacts are manifested. As pointed out by Gibbs 2009, this approach to ecological capacity is a social construct, encapsulated by the social carrying capacity. Gibbs defines ecological carrying capacity as the yield that can be produced without leading to significant changes to ecological processes, species, populations or communities. However, the assumption that aquaculture can produce yield without any significant ecological change is far from realistic. Moreover, the question remains what level of ecological change is acceptable for society, which is similar to the social carrying capacity.

In the approach of Inglis and others, ecological carrying capacity is not established as an intrinsic feature of the ecosystem like in the original concept as being the maximum population size supported by the ecosystem. Rather, ecological carrying capacity is now defined by what society considers acceptable, hence there is a circular argument: social carrying capacity is determined by what stakeholders 


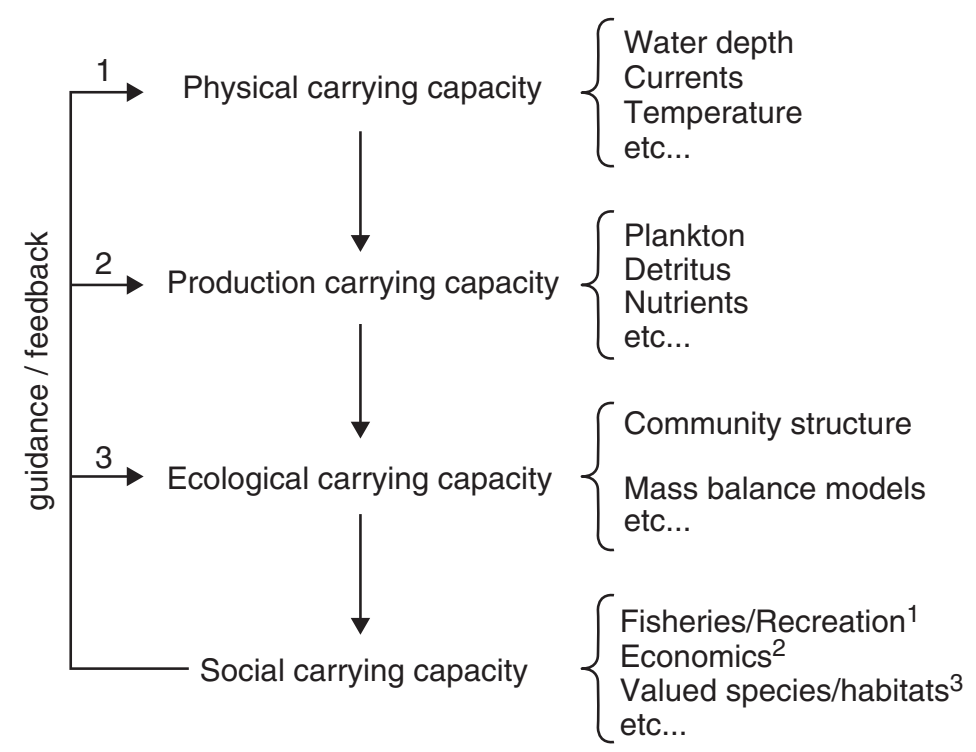

Fig. 23.1 Hierarchical structure of the different types of bivalve carrying capacity. Social carrying capacity provides guidance to choosing pertinent response variables and on establishing limits for these. Superscripts indicate examples of the type of information that informs the selection of response variables for other carrying capacity categories. (McKindsey 2013)

consider acceptable effects on ecological carrying capacity, and the ecological carrying capacity is defined by what stakeholders consider acceptable (Fig. 23.1).

McKindsey et al. 2006 and McKindsey 2013, following the definitions of Inglis et al. 2000, acknowledge the complexity of social and ecological carrying capacities. They propose a hierarchical approach, with physical capacity as a boundary condition for bivalve aquaculture, given the characteristics of the area and the needs of the farmers. Production capacity primarily depends on food availability i.e. primary production, transport of food through water movement and size of competing filter feeders stocks. Ecological carrying capacity is the level of change at which ecological impacts of bivalve aquaculture is considered acceptable for society. The question is how and by whom "acceptable" needs to be defined, as being a social concept. Indeed, McKindsey et al. 2006, 2013 consider social carrying capacity as the outcome of a process where the interests of all stakeholders are addressed. So in their approach, social capacity is defined in terms of the decision making process that leads to agreement on the level of ecological impacts that are considered acceptable.

Meanwhile there is a close link between production and ecological capacity. Firstly, establishing the cultured bivalve stock size that would give maximum yield, requires information about the size and activity of competing wild filter feeders stocks as they all depend on the same resources. Introduced filter feeder stocks, either as a side effect of bivalve aquaculture or by other causes, need to be included as well (Ruesink et al. 2005; Cugier et al. 2008). The same holds for bivalve stocks 
that are enhanced by bivalve restoration projects, as they also take their piece of the cake. The point that introducing filter feeders for bivalve aquaculture implies that other filter feeders will face food competition is explicitly addressed by Gibbs 2007. He points to the effects on the foodweb, for zooplankton in particular. This is substantiated by the model simulations as published in Byron et al. 2011b, where they calculated the impact of expansion of oyster culture on zooplankton and fish.

Secondly, cultured stocks can have positive and negative effects on the ecosystem, through various feedback processes. Addressing the different roles of cultured stocks in the ecosystem, specifically the ecosystem services they provide, not only for production but also for ecological response variables, is a prerequisite in understanding and managing the ecological carrying capacity for bivalve aquaculture.

\subsubsection{Impacts and Services}

The ecological impacts of bivalve aquaculture are a function of size of the culture and scale at which processes operate (farm scale / bay scale). This can be analysed for the pelagic habitat, the benthic habitat, and for the ecosystem functions (McKindsey 2013; see also the review by Filgueira et al. 2015). For the pelagic habitat, filtration of the water column by cultivated and wild filter feeders, in relation to food production and transport, is often used as an index for the carrying capacity at bay scale (Dame and Prins 1998; Gibbs 2009; Cranford et al. 2012).

For the benthic habitat, biodeposition and subsequent accumulation of organic material and potential oxygen depletion and sulphite release, are being used as impact parameters, particularly for suspended cultures (McKindsey 2013). Bivalve filtration and biodeposition enhance benthic-pelagic coupling, facilitating nutrient regeneration and denitrification (Cranford et al. 2007; McKindsey et al. 2011).

For ecosystem functions, the interactions between bivalve aquaculture and the ecosystem need to be addressed, as it concerns complex processes that provide ecosystem services. This includes filtration, biodeposition, nutrient regeneration (Jansen et al. 2019, this volume), selective retention of phytoplankton size classes impacting the pelagic food web structure (Cranford et al. 2009), interaction with higher trophic levels (Byron et al. 2011b; Aguera et al. 2015; Kluger et al. 2016a, b) as well as habitat modification and impacts on local biodiversity (Filgueira et al. 2015; Craeymeersch and Jansen 2019, this volume). These processes have an effect at farm scale as well as at bay scale. As mentioned by McKindsey 2013, these effects can act "positive" and "negative" on the carrying capacity.

Table 23.1 gives a summary of the main feedbacks that apply for bivalve aquaculture in the respective environments.

Various authors have proposed schemes for quantifying impacts as a basis for setting standards for ecological carrying capacity. McKindsey et al. 2006, proposed a conceptual scheme where the impact is plotted as a function of production level. This allows quantifying the maximum production level that gives an "acceptable" impact (Fig. 23.2). 
Table 23.1 Positive and negative feedbacks between bivalve aquaculture and the environment, based on McKindsey 2013, Filgueira et al. 2015 and Jansen et al. 2019, this volume

\begin{tabular}{l|l|l|l}
\hline Environment & Feedbacks on & Positive feedbacks & Negative feedbacks \\
\hline Pelagic environment & Food production & Nutrient regeneration & Phytoplankton depletion \\
\cline { 2 - 4 } & & Turbidity reduction & Zooplankton depletion \\
\cline { 2 - 4 } & & Dentrification & \\
\hline \multirow{2}{*}{ Benthic environment } & Habitat availability & Habitat creation & Degradation \\
\cline { 2 - 4 } & & $\begin{array}{l}\text { Increased niche } \\
\text { complexity }\end{array}$ & Resuspension \\
\cline { 2 - 4 } & & Coastal protection & \\
\hline Ecosystem functions & Food web & Predators & Pathogens, parasites \\
\cline { 2 - 4 } & & Benthic fauna & Invasive species \\
\cline { 2 - 4 } & & Fouling species & \\
\hline
\end{tabular}

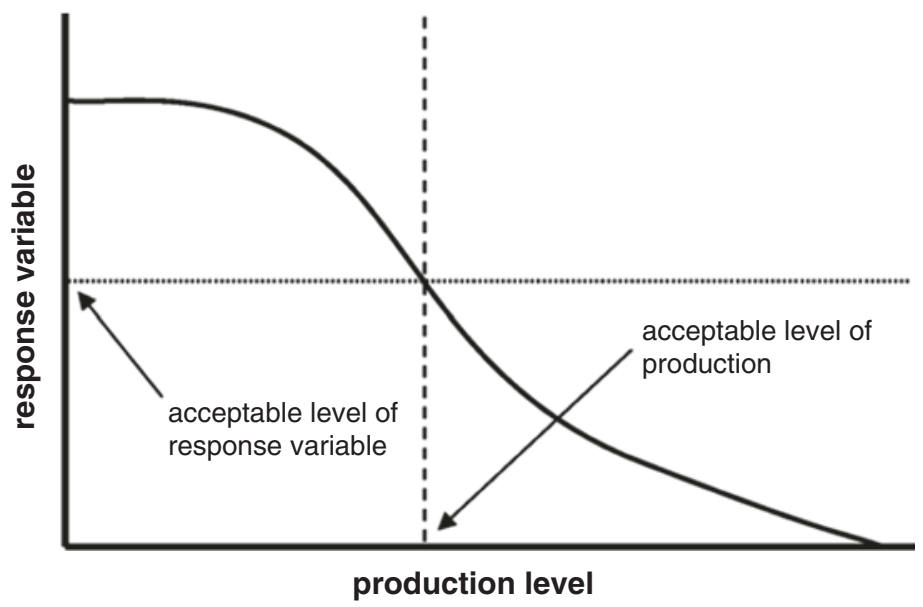

Fig. 23.2 Hypothetical response curve of an environmental variable as a function of bivalve production levels. The acceptable level of response gives the corresponding maximum production level. (McKindsey et al. 2006, see also Tett et al. 2011)

Although Cranford et al. 2012 and McKindsey 2013 refer to positive effects of bivalve aquaculture, the schemes do not explicitly address the bivalve services to the ecosystem. Therefore the hypothetical response curve can be extended to production levels of bivalve aquaculture that stimulate particulate response parameters, as reviewed by Jansen et al. (2019, this volume): Fig. 23.3. 


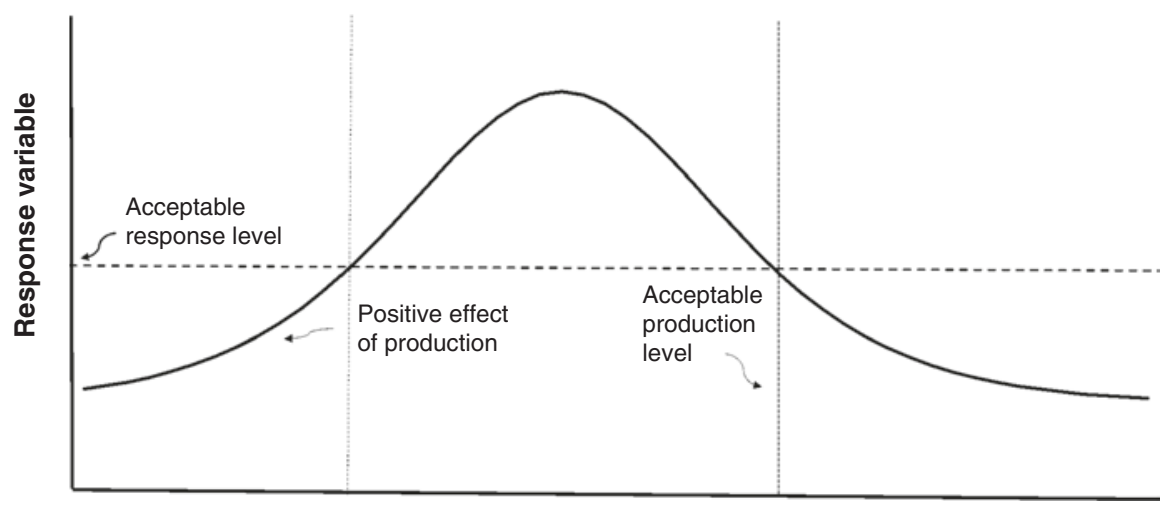

Production level

Fig. 23.3 Adapted hypothetical response curve of Fig. 23.2, showing that increase in bivalve production can stimulate a response variable from sub-optimal to an optimal level. Further increase of production leads to adverse impacts, below a level that is considered acceptable

\subsection{Approaches}

\subsubsection{Social Carrying Capacity}

Techniques for inferring social carrying capacity (SCC) are still being developed. It is considered as the most complex carrying capacity to determine, as it depends on various groups of stakeholders with different interests. Following the approach of McKindsey 2013, SCC is defined in terms of the decision making process that leads to agreement on the level of ecological impacts that are acceptable. Approaches to SCC deal with various decision making techniques: market, public regulation, multi-stakeholder agreements, and self-regulation (Table 23.2). These techniques are of a generic nature, not specific for bivalve aquaculture. For aquaculture this is based on criteria for the Ecosystem Approach to Aquaculture.

\subsubsection{Market}

It can be argued that economic carrying capacity is part of the social domain. Filgueira et al. 2015 explore social capacity from an economic perspective through the concept of "willingness to pay" that may be used to quantify consumer preferences. However, social capacity is generally considered in a much broader sense than can be quantified by economic approaches. 
Table 23.2 Various approaches to carrying capacity, the activity involved, required tools and management options (see below), and the actors

\begin{tabular}{|c|c|c|c|c|c|}
\hline $\begin{array}{l}\text { Carrying } \\
\text { capacity }\end{array}$ & Approach & Activity & Tools & $\begin{array}{l}\text { Management } \\
\text { options }\end{array}$ & Actors \\
\hline \multirow[t]{4}{*}{ Social } & $\begin{array}{l}\text { Market } \\
\text { economy }\end{array}$ & $\begin{array}{l}\text { "Willingness to } \\
\text { pay" surveys }\end{array}$ & Free market & $\begin{array}{l}\text { Secure level } \\
\text { playing field }\end{array}$ & $\begin{array}{l}\text { Consumers, } \\
\text { government, } \\
\text { research }\end{array}$ \\
\hline & Regulation & $\begin{array}{l}\text { Directives, } \\
\text { licensing }\end{array}$ & Standards & Licenses & Government \\
\hline & $\begin{array}{l}\text { Multi- } \\
\text { stakeholder } \\
\text { approach }\end{array}$ & $\begin{array}{l}\text { SES, LAC, } \\
\text { Convenant } \\
\text { partnerships }\end{array}$ & Agreements & $\begin{array}{l}\text { Process } \\
\text { facilitation }\end{array}$ & $\begin{array}{l}\text { Industry, } \\
\text { consumers, } \\
\text { government, }\end{array}$ \\
\hline & $\begin{array}{l}\text { Self- } \\
\text { organisation }\end{array}$ & $\begin{array}{l}\text { Labelling, best } \\
\text { practice }\end{array}$ & $\begin{array}{l}\text { Protocols and } \\
\text { assessments }\end{array}$ & Certification & $\begin{array}{l}\text { Industry, } \\
\text { consumers, } \\
\text { consultants }\end{array}$ \\
\hline \multirow[t]{4}{*}{ Ecological } & $\begin{array}{l}\text { Apply } \\
\text { standards }\end{array}$ & $\begin{array}{l}\text { Monitoring and } \\
\text { enforcement }\end{array}$ & Standards & Licenses & Government \\
\hline & $\begin{array}{l}\text { Site-specific } \\
\text { measures }\end{array}$ & $\begin{array}{l}\text { Appropriate } \\
\text { assessement for } \\
\text { licensing }\end{array}$ & Standards & Licenses & $\begin{array}{l}\text { Government, } \\
\text { industry, } \\
\text { consultants }\end{array}$ \\
\hline & $\begin{array}{l}\text { Knowledge } \\
\text { based } \\
\text { aquaculture }\end{array}$ & $\begin{array}{l}\text { Monitoring and } \\
\text { assessment }\end{array}$ & $\begin{array}{l}\text { Models, } \\
\text { indices }\end{array}$ & Scenarios & Researchers \\
\hline & Innovation & $\begin{array}{l}\text { R\&D; } \\
\text { developing } \\
\text { integrated } \\
\text { models }\end{array}$ & $\begin{array}{l}\text { Integrated } \\
\text { models }\end{array}$ & Scenarios & Researchers \\
\hline \multirow[t]{4}{*}{ Production } & Trial and error & $\begin{array}{l}\text { Yield and stock } \\
\text { monitoring }\end{array}$ & $\begin{array}{l}\text { Production } \\
\text { indices }\end{array}$ & $\begin{array}{l}\text { Learning by } \\
\text { doing }\end{array}$ & Industry \\
\hline & Site selection & $\begin{array}{l}\text { Collect data, } \\
\text { run scenarios }\end{array}$ & $\begin{array}{l}\text { Models, } \\
\text { indices }\end{array}$ & Licenses & $\begin{array}{l}\text { Industry, } \\
\text { consultants, } \\
\text { government }\end{array}$ \\
\hline & $\begin{array}{l}\text { Knowledge } \\
\text { based } \\
\text { aquaculture, } \\
\text { innovation }\end{array}$ & $\begin{array}{l}\mathrm{R} \& \mathrm{D} ; \\
\text { monitoring and } \\
\text { assessment }\end{array}$ & Models & Scenarios & $\begin{array}{l}\text { Industry, } \\
\text { researchers }\end{array}$ \\
\hline & $\begin{array}{l}\text { Self- } \\
\text { organisation }\end{array}$ & BMP, BEP & $\begin{array}{l}\text { Integrated } \\
\text { models }\end{array}$ & Scenarios & $\begin{array}{l}\text { Industry, } \\
\text { consultants }\end{array}$ \\
\hline \multirow[t]{3}{*}{ Physical } & $\begin{array}{l}\text { Identify } \\
\text { boundary } \\
\text { conditions }\end{array}$ & Collect data & Monitoring & Licenses & $\begin{array}{l}\text { Industry, } \\
\text { researchers, } \\
\text { government }\end{array}$ \\
\hline & Site selection & $\begin{array}{l}\text { Collect data, } \\
\text { run scenarios }\end{array}$ & Monitoring & Licenses & $\begin{array}{l}\text { Industry, } \\
\text { researchers, } \\
\text { government }\end{array}$ \\
\hline & $\begin{array}{l}\text { Knowledge } \\
\text { based } \\
\text { aquaculture }\end{array}$ & $\begin{array}{l}\mathrm{R} \& \mathrm{D} ; \\
\text { monitoring and } \\
\text { assessment }\end{array}$ & Monitoring & Scenarios & $\begin{array}{l}\text { Industry, } \\
\text { researchers }\end{array}$ \\
\hline
\end{tabular}




\subsubsection{Public Regulation}

Given limitation of the free market, governmental regulations are often required to handle conflicts about common resource exploitation. With respect to regulations, Sequeira et al., 2007 present an overview of legislation and worldwide policy instruments on the protection of the marine environment. It shows the various types of regulation that are implemented in China, USA, Europe and Australia/New Zealand. At global scale there is an apparent lack of UN regulations, although in the framework of the Convention on Biodiversity a global policy has been achieved for environmental protection (www.cbd.int).

\subsubsection{Multi-stakeholder Agreements}

Stakeholder support for regulation can often be a more effective approach than topdown rules. Ostrom 2009 evaluated management strategies of social-ecological systems (SES, Walker et al. 2003) - that can also be used for analysing social carrying capacity - and showed that proper stakeholder involvement delivered a more sustainable approach than top-down rules (McKindsey 2013). The concept of "limits of acceptable change" (LAC) is about indicator selection through a collaborative approach, rather than setting limits as such. Application in the case of New Zealand bivalve aquaculture showed that this approach provides a management framework to prevent negative effects of the activity, supported by stakeholders (Zeldis 2005). There are many ways to organise multi-stakeholder involvement, depending on site specific social, economic and cultural factors. The concept of social-ecological systems stress the idea that society is part of the ecosystem, hence it is logical to include relevant stakeholders, as is also acknowledged in the ecosystem approach to aquaculture.

\subsubsection{Self-Organisation}

Self-organisation by the industry aims to achieve self-imposed goals either through Good Agricultural Practices (GAP), Codes of Practice and Codes of Conduct, implemented through Best Managing Practices (BMP) (Hargreaves 2011). Labelling is also part of self-organisation. This is done for aquaculture and fisheries - including extensive bivalve cultures as enhanced fisheries - through ASC and MSC certification respectively. Self-organisation is generally inferred through external pressure, like from retailers and consumer interests.

For all approaches to infer social carrying capacity, it is a challenge to focus on both sides of bivalve aquaculture: ecological impacts as well as ecological benefits. 


\subsubsection{Ecological Carrying Capacity}

Ecological carrying capacity (ECC) is about the various positive and negative feedbacks between bivalve aquaculture and the ecosystem (Table 23.1), and about what is decided at the level of social capacity with regard to management aims. According to the Ecosystem Approach to Aquaculture, this should not only focus on avoiding unacceptable impacts, but it should take into account bivalve ecosystem services that reinforce management aims, such as, for example, ecosystem resilience. In the current approaches, however, focus is merely on avoiding adverse impacts.

\subsubsection{Standards}

The general approach to environmental impacts is based on standards that define the acceptable impact level of a given activity for a given environment. Application of standards is based on the idea that there are threshold values for various parameters that should not be exceeded. Standards are straightforward, relatively simple and relatively easy to implement and to reinforce. However, once defined they are static and any adjustment is complicated. Moreover, positive feedbacks are generally not taken into account. Therefore more dynamic approaches are being developed, like, for example, thresholds of potential concern (TPC). TPCs are a set of operational goals along a continuum of change in selected environmental indicators. TPCs are being continually adjusted in response to the emergence of new ecological information or changing management goals (Cranford et al. 2012). The previously mentioned LAC approach (Limits of Acceptable Change) is also more dynamic as it is used as a basis to achieve consensus in multi-stakeholder groups.

\subsubsection{Site-Specific Measures}

Site-specific measures have the potential to address ecosystem characteristics of the bivalve aquaculture environment. In many cases this is the natural ecosystem in relatively undisturbed areas. Bivalve aquaculture requires relatively unpolluted water, in many countries regulated by water quality standards for bivalve production. It turns out that bivalve production waters are now recognised as areas of high natural value. Hence they attract attention to be protected in the framework of nature conservation. In the European Union, for example, this is regulated in the framework of the Natura 2000 policy. Natura 2000 is a network of core breeding and resting sites for rare and threatened species, and some rare natural habitat types which are protected in their own right. The aim of the network is to ensure the longterm survival of Europe's most valuable and threatened species and habitats listed under the Birds and Habitats Directives, approved by national laws (http://ec.europa. eu/environment/nature/natura2000). In these areas an activity such as bivalve aquaculture is only allowed through a permit of the government. To achieve a permit the 
farmer has to prove that there is no negative impact of the activity on the maintenance goals that are set for the given area. So the standard is in this case the absence of negative impacts on a given set of parameters, like numbers of protected bird species. In principle this approach could take positive impacts into account. In practice, however, the standards are based on the absence of negative impacts.

\subsubsection{Knowledge Based Aquaculture}

In this approach available knowledge about the interactions between bivalve aquaculture and the ecosystem is mobilized to evaluate positive and negative feedbacks. This requires empirical data of key ecosystem parameters and processes. As this is rather complex, in many cases mathematical models are used to integrate data. With these models processes can be simulated in order to address the optimum level of bivalve aquaculture giving the maximum level of ecological response (Fig. 23.3). A formal scheme to address the impact was applied by Tett et al. 2011 following the driverpressure-status-impact-response (DPSIR) approach; see also Nobre 2009 for dynamic DPSIR application in decision making. If not many data are available, indices like presented by Dame and Prins 1998 can be used to identify the relation between bivalve stock size, water renewal and food production (see case study below).

\subsubsection{Innovation}

An innovative approach to ecological carrying capacity would require information of the various goods and services that a specific bivalve aquaculture activity provides for the ecosystem. This includes interactions in the water column, in the benthic system and in the ecosystem functions. Given the complexity of the interactions, models are needed to integrate data and processes (Smaal et al. 1998). As reviewed by Filgueira et al. 2015 various types of models are being used for estimating carrying capacity for bivalve aquaculture. This includes farm models, spatial models, food web models, benthic models and habitat models. See also Newell et al. (2019), Grant and Pastres (2019), Ferreira et al. (2019) and Bacher et al. (2019) this volume. Yet a generic integrated approach where the various ecosystem services of bivalve aquaculture, like habitat provisioning, facilitation and nutrient control, are included in an integrated model, is still to be developed.

\subsubsection{Production Carrying Capacity}

\subsubsection{Trial and Error}

Although production carrying capacity (PCC) of the ecosystem is the most studied type of bivalve aquaculture carrying capacity (McKindsey 2013) the approach most applied in practice, seems to be based on trial and error. This sounds logical as the 
farmers are well equipped to estimate ups and downs in the yields and should be able to make the link with variation in the size of the stock that they are controlling. However, this can be obscured by dynamics of other filter feeder stocks, either natural or commercial. Other factors like elevated predation, will also influence yields. So, data on stock size as a basis for PCC management are indispensable. This not only concerns total commercial filter feeder stocks in the culture area, but also natural, restored and introduced stocks of filter feeders.

\subsubsection{Site Selection}

PCC depends on local conditions like stability of the sediment for bottom culture, water flow for food supply and waste dispersal, and hydrodynamic forces for suspended culture. So, at farm scale level data is needed of these variables to select optimal sites.

\subsubsection{Innovation}

For PCC, as for ECC, innovation concerns the development of tools and models that take positive feedbacks into account, as a basis for ecosystem services. Given the state-of-the-art, it can be considered innovative if the industry would apply models that allow the calculation of the optimum stock size to provide maximum yield of their cultures. This not only requires proper calculations but also cooperation in managing the stock size. As individual farmers use the common pool as a resource they have to organise themselves to overcome the "tragedy of the commons".

\subsubsection{Self-Organisation}

In addition to self-organisation as mentioned under SCC, approaches like Best Management Practice (BMP) are described for bivalve aquaculture in the framework of sustainable aquaculture (Hargreaves 2011). As pointed out by Hargreaves 2011, BMP is an approach at farm scale that has limitations for the wider scale, although within producer organisations collective approaches for BMP are applied. Yet it remains a voluntary activity that often lacks sufficient assessment and monitoring.

\subsubsection{Physical Carrying Capacity}

Physical carrying capacity defines the boundary conditions in physical terms for the extent of bivalve culture in a certain area. This depends on hydrodynamics (currents, waves, wind forcing), bathymetry, water quality and available space. The 
approach is to collect data of the key parameters and identify proper sites. Generally new sites will need pilots to test the proper conditions at the local scale in practice.

\subsubsection{Integrated Carrying Capacity}

There is a direct link between social, ecological and production carrying capacity. Sequeira et al., 2007 show that partitioning of food for example, between wild and cultivated stocks differs considerably between culture areas in China and Europe, with a much greater portion for bivalve aquaculture than for wild stocks in the Chinese cases, in comparison with the European cases. They clearly show that the proportion of ECC vs PCC can be quite different in different societies, reflecting differences in SCC. In countries where food production is acknowledged as a high priority issue by society, PCC is dominant over ECC. In countries with a large environmental concern in society, this seems to be the reverse. However, the Ecosystem Approach to Aquaculture, that aims to address goods and services of aquaculture and to inform and involve stakeholders, might provide a common framework for an integrated approach of carrying capacity (Byron et al. 2011b; Filgueira et al. 2015). In this approach, the challenge is to achieve a carrying capacity for bivalve aquaculture where commercial stocks attribute in a balanced way to production, ecological and social goals (cf Triple P, see also Cranford et al. 2012).

\subsection{Tools}

For managing bivalve aquaculture in the natural environment, tools are needed to estimate the different types of carrying capacity and to identify the optimal production level in relation to management goals of a given area. Therefore we will discuss indicators and models as tools to address the interaction between bivalve aquaculture and the ecosystem, and their relevance for decisions on how to manage carrying capacity.

\subsubsection{Indicators and Indices}

Bivalve carrying capacity indicators should address the positive and negative impacts of bivalve aquaculture for production and ecological carrying capacity. We use an indicator as a parameter to establish the value of a variable or a set of parameters with a specific meaning, often called an index; an index is a calculation based on a set of variables, that can be used for comparative analysis.

In their review on tools for sustainable management, Cranford et al. 2012, discussed pelagic, benthic, production performance and socio-economic indicators of 
bivalve aquaculture. Pelagic indicators address the influence of bivalve suspended and bottom culture farms in the water column; for the pelagic system the interaction between the bivalves and their food is the most important determinant of both PCC and ECC. Benthic indicators address the impact of suspended culture on the benthic habitat, comprising of the effect of organic enrichment of the sediment, and the consequences for the benthic community. Benthic indicators predominantly describe impacts at farm scale rather than bay scale, while pelagic indicators tend to be more relevant at bay scale. Production indicators, like bivalve condition indices and yield, address the effectiveness of the culture practice in the given environment and provide a tool to evaluate culture measures. For socio-economic indicators, Cranford et al. (2012) refer to the social acceptability of the bivalve culture, the supply availability to the market, the livelihood security for the local communities, and the economic efficiency of bivalve culture operations. These indices and indicators can be used to address the effects of bivalve aquaculture on the social carrying capacity (Table 23.3).

\section{Case Study: Pelagic Indices}

For the various pelagic indicators as shown in Table 23.3, the ones that address the interaction between the bivalves and their food - phytoplankton biomass, depletion index - directly link to carrying capacity. As shown by Filgueira et al. 2015, the use of "depletion" in the literature to address the uptake of particles by the bivalves, may suggest exhausting of algal cells. This would indicate a rather extreme case of overgrazing, while filtration in combination with nutrient regeneration can also stimulate food availability. Rather than depletion, indicators for the interaction between the bivalves and the pelagic processes should take into account in how far particle filtration is compensated by renewal of the particle stock by import from outside and local primary production. This has been worked out by Dame and others (Smaal and Prins 1993; Dame 1996; Dame and Prins 1998; Prins et al. 1998). They describe the impact of the bivalves on processes in the water column in relation to the water residence time and the primary production in the Bay. Water residence time (RT) is the time it takes to renew the water body by exchange water from a defined area with the adjacent ecosystem. Primary production time (PT) is the time it takes to renew the phytoplankton stock in a given area. Clearance time (CT) is the time it takes for the bivalves to filter the water body in a given area. See Dame and Prins 1998 for the calculations. We define $\mathrm{CT} / \mathrm{RT}$ as the clearance ratio, and $\mathrm{CT} / \mathrm{PT}$ as the grazing ratio. If the clearance ratio $(\mathrm{CT} / \mathrm{RT})>1$, then water renewal time is shorter than bivalve clearance time, hence the system is relatively open and the bivalves have little control over the ecosystem. At a clearance ratio $<1$, bivalves filter the water column faster than this water is renewed, hence the bivalves potentially control pelagic processes through their grazing activity. In this case the internal primary production determines the carrying capacity, and this is expressed as PT. At a grazing ratio $(\mathrm{CT} / \mathrm{PT})>1$, primary production exceeds bivalve filtration capacity, hence food is produced faster than consumed. At a grazing ratio $<1$ the system will collapse as food is depleted. Actually if the grazing ratio is just above 1, the system will be unstable as depletion due to daily variation in primary production may occur. 
Table 23.3 Potential indicators of bivalve aquaculture impacts in the framework of sustainable management (see Cranford et al. 2012 for descriptions of the indicators)

\begin{tabular}{|c|c|c|c|c|}
\hline $\begin{array}{l}\text { Pelagic } \\
\text { indicators }\end{array}$ & Sediment indicators & $\begin{array}{l}\text { Benthic } \\
\text { community } \\
\text { indicators }\end{array}$ & $\begin{array}{l}\text { Production } \\
\text { indicators }\end{array}$ & $\begin{array}{l}\text { Socio-economic } \\
\text { indicators }\end{array}$ \\
\hline $\begin{array}{l}\text { Nutrient } \\
\text { concentration }\end{array}$ & Sedimentation rate & $\begin{array}{l}\text { Biodiversity } \\
\text { metrics }\end{array}$ & $\begin{array}{l}\text { Bivalve } \\
\text { growth rate }\end{array}$ & Profitability \\
\hline $\begin{array}{l}\text { Dissolved } \\
\text { oxygen }\end{array}$ & Biodeposition rate & Indicator species & $\begin{array}{l}\text { Conditon } \\
\text { index }\end{array}$ & Total employment \\
\hline $\begin{array}{l}\text { Bacterial } \\
\text { abundance }\end{array}$ & Sediment texture & Trophic indices & Meat yield & $\begin{array}{l}\text { Gross value } \\
\text { added/ } \\
\text { employment }\end{array}$ \\
\hline $\begin{array}{l}\text { Phytoplankton } \\
\text { biomass }\end{array}$ & Onanie enrichment & $\begin{array}{l}\text { Benthic } \\
\text { similarity }\end{array}$ & $\begin{array}{l}\text { Stocking } \\
\text { density }\end{array}$ & Tax revenues \\
\hline Depletion index & $\mathrm{N}$ and $\mathrm{P}$ enrichment & & $\begin{array}{l}\text { Production } \\
\text { time series }\end{array}$ & $\begin{array}{l}\text { Socia1 } \\
\text { acceptability }\end{array}$ \\
\hline $\begin{array}{l}\text { Phytoplankton } \\
\text { size }\end{array}$ & Sediment quality & & & $\begin{array}{l}\text { Conflict } \\
\text { assessment }\end{array}$ \\
\hline \multirow{9}{*}{$\begin{array}{l}\text { Trophic } \\
\text { heterogeneity }\end{array}$} & Redox potential & & & \\
\hline & Total free sulfides & & & \\
\hline & Water content & & & \\
\hline & Dissolved oxygen & & & \\
\hline & Benthic/pelagic flux & & & \\
\hline & Pigments & & & \\
\hline & Visual observations & & & \\
\hline & $\begin{array}{l}\text { Benthic Enrichment } \\
\text { Index (BEI) }\end{array}$ & & & \\
\hline & $\begin{array}{l}\text { Benthic Habitat } \\
\text { Quality Index (BHQ) }\end{array}$ & & & \\
\hline
\end{tabular}

Therefore in practice, a buffer capacity is required for a stable solution. This indicator tool has been used in various studies to estimate carrying capacity (Gibbs 2007; Thompson 2005; Filgueira et al. 2015). In his paper of 2007, Gibbs used the term clearance efficiency for the ratio between CT and RT. He defined Filtration Pressure being the food uptake rate as a fraction of primary production; this resembles the grazing ratio. The Regulation Ratio is defined as the Clearance Rate relative to the water mass $(=1 / \mathrm{CT})$, as a fraction of the phytoplankton turnover rate $(=1 / \mathrm{PT})$. So $\mathrm{RR}=(1 / \mathrm{CT}) /(1 / \mathrm{PT})$ which is similar to the inverse of the grazing ratio.

The clearance and grazing ratios have the elegance of simplicity, but limitations are the lack of spatial and temporal differentiation and assumptions about mixing of the water body and various eco-physiological processes. In cases where not many data and no models are available, these indicators can be used to characterize the potential of an area for bivalve aquaculture. It also has been used to make a comparative analysis of different culture areas, or changes over time. It should be noticed that clearance time by the cultured stocks does not represent total clearance time that includes wild, invasive and restored stocks. 
We analysed 20 areas that are used for bivalve aquaculture and we made a comparison on the basis of existing literature values. Only for a limited number of areas distinction can be made between different stocks, as shown in Annex I.

Figure 23.4 shows the log transformed clearance ratio, showing areas with positive values that have a clearance time larger than the water residence time in the right panel, and in the left panel the areas with a clearance time shorter than the residence time. In these areas the bivalves potentially control pelagic processes.

Figure 23.5 shows the Grazing Ratio in areas where clearance time is shorter than water residence time. This means that in these areas the local primary production is the main factor determining carrying capacity. The grazing ratio in these areas ranges from below 1 to over 11. The graph shows changes over time for The Oosterschelde (SW Netherlands), as grazing ratio was 3.4 in 1996, then went down to 2.5 in 2009. This is consistent with the expansion of the invasive Pacific Oyster stocks, as shown in Smaal et al. 2013. Also for the Western Wadden Sea the grazing

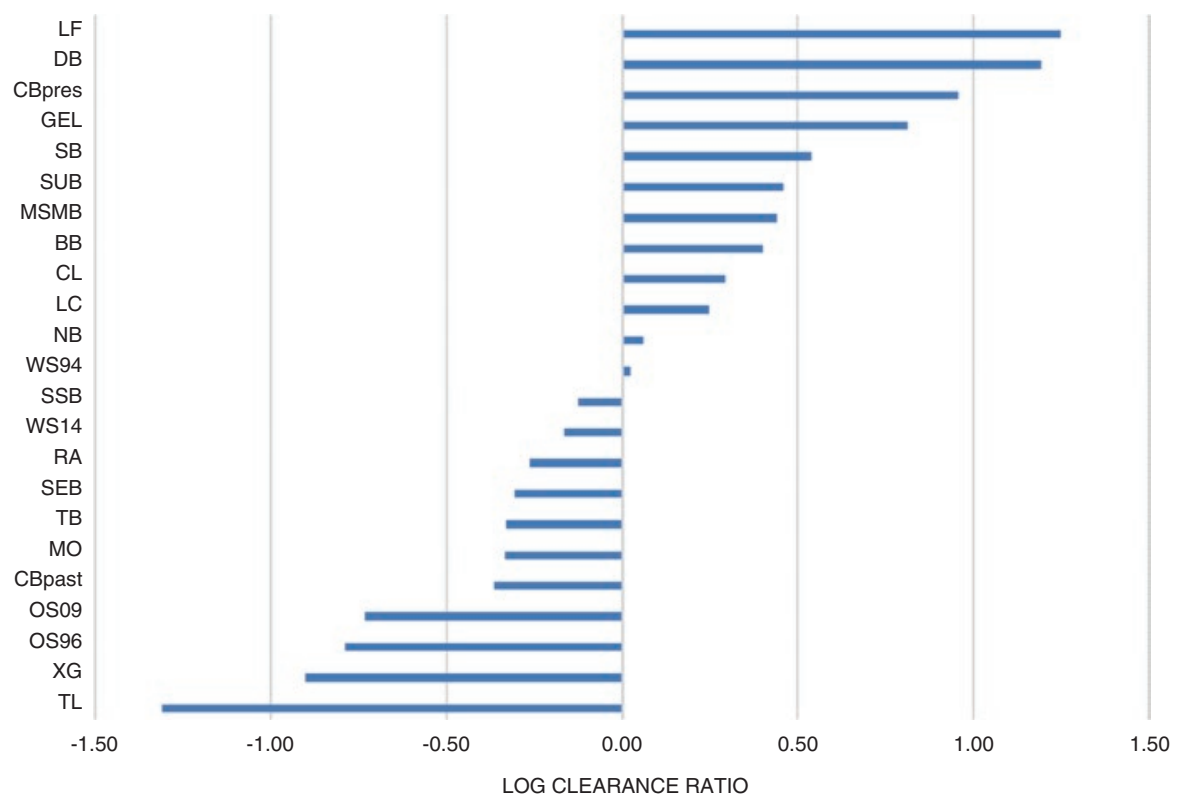

Fig. 23.4 Log Clearance Ratio (CT/RT) of areas with bivalve aquaculture. Values $>0$ show areas with faster water renewal than water potentially cleared by the bivalves. This holds for Lysefjord (LF, Norway), Delaware Bay (DB, USA), Chesapeake Bay present (CBpres, USA), Grand Entree Lagoon (GEL, Canada), Saldanha Bay (SAB, S-Africa), Sungo Bay (SB, China), Mont St Michel Bay (MSMB, France), Beatrix Bay (BB, N-Zealand), Loch Creran (LC, UK), Narragansett Bay (NB, USA) and Wadden Sea 1994 (WS94) (see Annex I for details and references)

Values $<0$ show areas where bivalve filtration potentially regulates water column processes as clearance time is shorter than residence time; this is the case for South San Francisco Bay (SSB, USA), Western Wadden Sea 2014 (WS14, The Netherlands), Ria de Arosa (RA, Spain), Sechura Bay (SEB, Peru), Tracadie Bay (TB, Canada), Marennes-Oleron Bay (MO, France), Chesapeake Bay past (CBpast, USA), The Oosterschelde in 1996 and 2009 (OS, The Netherlands), Xiangang Bay (XG, China) and Thau Lagoon (TL, France) 


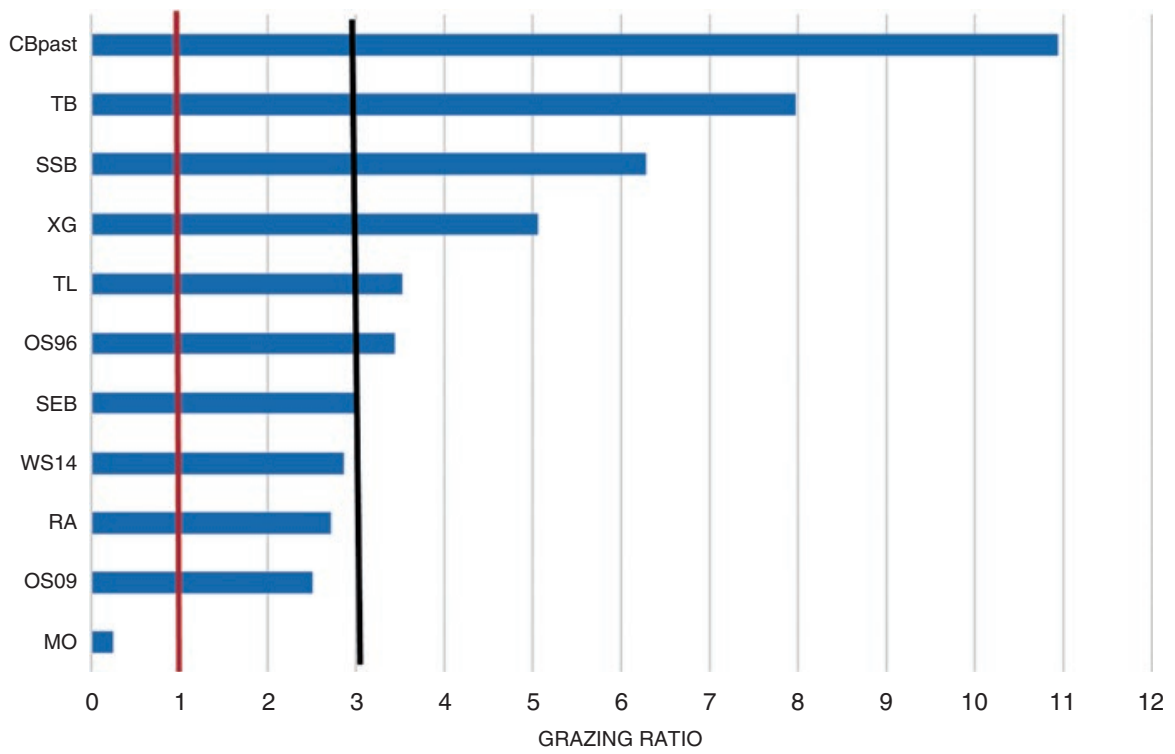

Fig. 23.5 Grazing ratio in areas with a Clearance Ratio $<1$, abbreviations in legend of Fig. I.1. Red line shows the theoretical minimum grazing ratio below which the system collapses; the black line gives the threshold of potential concern (TPC) value as set by the ASC; between 1 and 3 the system has the risk of overgrazing

ratio is now 2.86, while in 1994 it was 5.9 (Annex I). This is ascribed to the expansion of the invasive species Crassostrea gigas and Ensis americanus.

As mentioned before, areas with a grazing ratio around or smaller than 1 are considered unstable, as in these areas, the short clearance time will exhaust primary production. For Marennes-Oleron Bay it is known that microphytobenthos is a major food source for the bivalves that is not represented in primary production data (Héral et al. 1988). The grazing ratio should in practice be above 1. The ASC has set a limit of 3 as a minimum value, a Threshold of Potential Concern. The graph shows that areas such as the Oosterschelde, Ria de Arosa and the Western Wadden Sea have values between 2 and 3. It should be noted that this regards the grazing ratio of the combined cultivated, wild and invasive stocks. Expansion of bivalve aquaculture in these areas requires decisions on the production versus the ecological carrying capacity, and on the fate of invasive stocks.

\subsubsection{Models}

There are several modelling tools available that are specifically designed to assess carrying capacity, and there are more generic ecosystem models that can also be used to assess system limits in terms of carrying capacity. The basic ones are 
generally relatively simple box models (Dowd 2005; Grant et al. 2007), the more sophisticated ones are fully coupled physical - ecological models that are spatially explicit.

Models have to be fit for purpose. Some questions do not require very elaborate modelling. To get a first order impression of whether a system is approaching carrying capacity for bivalve, relatively simple models that include data on grazing rates, primary production rates and retention times will suffice. Other questions regarding optimal locations and optimal spacing of bivalve farms need much more explicit detail on transport of nutrients, algae and other constituents and therefore at the very least need a well validated hydrodynamic model as a basis.

\subsubsection{Physical Carrying Capacity}

Physical carrying capacity is basically determined by the availability of suitable habitat. For benthic bivalve beds (natural as well as cultivated) this is determined by the combination of bivalve bed composition (hard or soft substrate); fluid dynamics (high bed shear stress on soft sediment limits settlement possibilities) and parameters such as oxygen concentration. Areas with regular stratification and extended periods of oxygen depletion near the bed will not have bivalve beds, even if there is plenty of food supply (but see Petersen et al. 2013). Habitat models can be used to ascertain the physical carrying capacity for bivalves (and other species) in ecosystems (Cozzoli et al. 2014; Brinkman et al. 2002). They rely on relationship of the bivalves for each parameter in the model and spatial information on the range of values of these parameters in each model. The approach by e.g. Cozzoli et al. (2014) is based on non-linear quantile regression analysis, a powerful statistical method that (given enough data) can be used to set up a predictive model for the distribution of species, related to environmental characteristics such as grain size. Other models calculate a habitat suitability index based on the upper and lower limits of characteristics that bivalves and the optimum range of these limits where they occur (e.g. Barnes et al. 2007).

In systems with benthic cultures, physical carrying capacity may be a limiting factor, particularly in systems with a very large exchange rate (i.e. small retention time) where food supply is large and suitable space limited. In systems with rope cultures the physical carrying capacity is artificially increased by providing suitable physical habitat (generally also outside oxygen depleted layers) and generally not an issue.

\subsubsection{Production and Ecological Carrying Capacity}

Production carrying capacity and ecological carrying capacity are determined by food supply and models need to capture the relationship between local (system) primary production, import of algal biomass from external sources, and cultivated bivalves and natural grazing stocks. 
Models can act at different scales. At the scale of a farm local depletion is very relevant, determining local stocking density (Cranford et al. 2014; Newell et al. 2019 , this volume). These models give some information on production carrying capacity at very local scales. In terms of carrying capacity of ecosystems for bivalves, farm-scale models are of limited interest. Even if strong depletion occurs within a farm, this does not imply that there are problems with carrying capacity (either production or ecological) in the system as a whole. These models are therefore not considered further here, we concentrate on regional or ecosystem-scale models.

Particularly when considering ecological carrying capacity, it is imperative to consider not only the growth of cultivated bivalves, but also the transfer of carbon (or energy) to other trophic levels. Foodweb models such as Ecopath with Ecosim (EwE - www.ecopath.org) have proved very valuable to assess energy flows between different trophic levels between different species (Wolff et al. 2000). The EwE approach has been used in the Mississippi Delta plain to assess the effect of large scale river diversions on landings of bivalve and fish (Mutsert et al. 2017), using the Delft 3D hydrodynamic modelling suite to provide boundary conditions on transport and primary production. This approach works very well for impact studies where the major changes in the system are physical and not strongly influenced by feedback processes mediated by the bivalves themselves.

For 'true' carrying capacity studies on bivalves, these feedback mechanisms are crucial to consider. In most systems primary productivity is determined by nutrient and light availability. In bivalve dominated systems, the grazing activity of the bivalves strongly influences both these factors. Filtration activity lowers the algal concentration in the water as well as removes fine sediment particles from the water column. This reduces light attenuation and increases productivity in light limited systems. The remineralisation of nutrients increases nutrient availability in systems that are nutrient limited (Van Broekhoven et al. 2014; Jansen et al. 2019, this volume). In bivalve dominated systems (i.e. many systems with large scale bivalve cultures) it is not possible to accurately model primary production without taking these feedback loops into account. Therefore it is in such systems also not possible to accurately calculate bivalve or primary production without a dynamic coupling between bivalve growth and primary production (Filgueira et al. 2015).

In recent years, major advances have been made with fully integrated online coupling of ecosystem hydrodynamics models with nutrient dynamics, light attenuation, primary production and bivalve growth. Bivalve growth is sometimes parameterised as Scope for Growth (SfG), but more often bivalves are modelled using Dynamic Energy Budget modelling (Kooijman 2010; Troost et al. 2010; Guyondet et al. 2010). In this modelling concept, energy entering an organism can be used for either reproduction, or for maintenance, or it can be stored. The model relies on accurate parameterisation of functional responses to environmental variables (food availability, food quality temperature, particulate matter concentrations etc.) that have to be determined for each species, for each system. Depending on the spatial organisation of the model, this approach gives the opportunity to assess ecological carrying capacity and production carrying capacity for bivalve culture at different 
spatial scales (Guyondet 2010). With this approach (and assuming all parameters are available) it is in principle possible to have multiple bivalve stocks (natural and cultivated) competing for phytoplankton in the same system (Troost 2011 - in Dutch). This allows the assessment of bivalve cultivation on natural bivalve stocks. The study by Troost (2011) yielded response curves for increasing levels of bivalve culture very similar to the conceptual picture in Fig. 23.3. While the unidirectional models have proven their value in indicating the limits of carrying capacity and the potential damage of bivalve aquaculture to the system, the lack of including feedback mechanisms limits their ability to quantify potential benefits.

At present there are no modeling tools available that include the carbon or energy fluxes in a system as well as habitat characteristics. For a comprehensive assessment of ecological carrying capacity it is important that not only the trophic interactions are taken into account, but that also other ecological functions are assessed. For example, bivalves are ecosystem engineers (Passarelli et al. 2014; Ysebaert et al. 2019, this volume). Epibenthic bivalves can transform soft sediment into hard substrate, altering the physical state of the environment and providing habitat for a different range of biota. This is true for benthic assemblages, but also rope cultures can become hotspots of associated fauna and change the species composition in ecosystems. Sometimes these effects of bivalves are seen as very positive. The loss of large scale reef structures of flat oysters from the North Sea has decreased its biodiversity and led to the North Sea being considered an impoverished system. However, very large assemblages of cultivated bivalves may also lead to a switch in species composition due to these ecosystem engineering effects. E.g. in Sechura Bay in Peru, an increased cultivation of the Peruvian scallop, Pacoplecten purpuratus, led to large-scale shifts in the species composition in the bay. This significant change in benthic community composition, together with an increase in the predator biomass, paralleled by a decrease in the biomass of their competitors; a change in species diversity and maturity; a system increase in size (in terms of biomass and total flows) and a decrease in energy cycling, led to the conclusion that the ecological carrying capacity of the system had been transgressed (Kluger 2016b). The energy cycling was investigated in this study with an EwE model, the other effects were addressed deriving indicators from datasets.

\subsubsection{Social Carrying Capacity}

There are also models available to calculate social carrying capacity, however at present these do not seem to have been applied to carrying capacity for bivalve cultivation. Most applications of model calculations on social carrying capacity have been applied to tourism and to the adaptive management of e.g. national parks (e.g. Lawson et al. 2003) or recreational areas (e.g. Tarrant and English 1996). These are tools that consider a relatively limited set of parameters, generally based on interviews with stakeholders, assessing their tolerance levels for particular activities or number of tourists in the area. Social carrying capacity is influenced by economic arguments (so production carrying capacity and communication surrounding the 
maximum profitability of bivalves) and by arguments as well as regulations regarding ecological carrying capacity (in many areas there is legislation (national or in the form of EU directives) determining boundaries of what society sees as acceptable impacts). Byron et al. (2015) produced one of the first modelling approaches to integrate ecological and socio-economical aspects of bivalve aquaculture. Such modelling tools can be very valuable in communication about the costs and benefits of aquaculture to society and perhaps increasing the social carrying capacity for aquaculture. Although, these models do not assess social carrying capacity in itself, they may become increasingly important in adaptive management of systems.

\subsection{Carrying Capacity Management}

Management of bivalve aquaculture involves the bivalve industry, governmental organisations and other stakeholders such as consumers, environmental NGO's and other users of the culture areas like fishermen and recreationists. Decisions on how to manage carrying capacity, deal with the level of production that is commercially feasible, as well as considered acceptable by society. Hence stakeholders need to decide on what is acceptable, and governmental organisations need to implement regulations and management systems. Tools to support this process need to provide the required information on possible impacts, what if scenarios and target values of the management aims, such as standards, thresholds of potential concern (TPC), risk assessments or development scenarios. In Table 23.2 tools and options for managing the various approaches of bivalve carrying capacity have been summarized.

Bivalve aquaculture usually requires a license to operate a farm in a certain area. To acquire a license it has to be proven that the impact of the culture is within acceptable limits. The limits are often implemented as standards or thresholds. As an example, the impact of suspended culture for the quality of the benthic environment can be evaluated by using the level of free sulphite as an indicator. A threshold value of $1500 \mu \mathrm{M} \mathrm{S}^{2-}$ is set as a TPC in the Aquaculture Stewardship Certification (WWF 2010). The ASC also has set a threshold for the pelagic impacts in the form of a grazing ratio of 3 at minimum (WWF 2010). Other carrying capacity thresholds are still under development. In Natura 2000 areas in Europe, TPCs are being developed to protect birds that feed on bivalves that may be in competition with bivalve aquaculture. As this should not have a negative impact on the availability of intertidal bivalves as feed for birds, a monitoring and modelling program is carried out to quantify the impact of seed mussel collectors in Dutch coastal waters on intertidal cockle populations that are a prerequisite for protected birds like the Oystercatcher (Kamermans and Capelle 2019, this volume).

As mentioned before, the Ecosystem Approach to Aquaculture aims to achieve a carrying capacity management for bivalve aquaculture where commercial stocks attribute in a balanced way to production, ecological and social goals. This approach, based on the ecosystem services concept, asks for a management system that is based on knowledge of the complex interactions between bivalve aquaculture and 
the ecosystem, rather than whether standards are met or thresholds are not surpassed. This is the domain of scenario analysis that can make use of advanced modelling to quantify the effects of different management decisions. Examples in literature deal with what if scenarios that calculate the impact of expansion of aquaculture stocks to a level that generates adverse effects, as shown in the model paragraph.

A fundamental question arises when the various categories of competing filter feeders are taken into account. Expansion of bivalve aquaculture will involve increased competition for food with other plankton consumers, varying from other bivalves to predatory ciliates. This is based on the idea that production and consumption are in balance, hence expanding bivalve aquaculture means decrease in other consumer groups. In a bivalve filter feeder dominated ecosystem in a moderate climate, the year-round appearance of bivalve filter feeding in contrast to the seasonal cycle of zooplankton, prevents a dominance of zooplankton (Herman and Scholten 1990). If we disregard the role of heterotrophic micro-organisms, bivalve aquaculture competes for food with the following dominant categories: wild bivalves stocks, comprised of native stocks, invasive stocks and in some cases restored stocks; in addition there are stocks of tunicates, sponges and other epibenthic filter feeders, including fouling organisms on the aquaculture structures that depend on phytoplankton. Hence the basic management question is about the partitioning of available food between these categories. A critical analysis of the role of invasive stocks has led to management measures in Europe to keep them under control (EU 2017). This is of practical relevance for managing bivalve stocks in the Oosterschelde (NL), for example. Competition of wild stocks of the Pacific oyster Crassostrea gigas with commercial stocks of the Pacific oyster has provoked efforts to remove wild oyster beds by oyster farmers to maintain the production capacity for their culture (Smaal et al. 2009, 2013). Also in areas such as the Mont St Michel Bay, management of the slipper limpet is investigated as this invasive species has the largest biomass of all bivalves in the Bay and is considered a threat for bivalve aquaculture (Cugier et al. 2008).

Management of competing stocks with different roles in the ecosystem requires an integrated approach, based on knowledge of their ecosystem services, and the relevance for various stakeholders. The Ecosystem Approach to Aquaculture provides a framework for bivalve aquaculture management that takes ecosystem services into account as well as stakeholder interests.

\subsection{Conclusions}

1. The carrying capacity concept for bivalve aquaculture has been applied to assess production potential of culture areas, and to address possible effects of the culture for the environment and for other users. Production potential is depending on physical and production carrying capacity of the ecosystem, while ecological and social carrying capacity determine in how far the production capacity can be 
realized. This is embedded in the Ecosystem Approach to Aquaculture that says that ecosystem functions, services and resilience have to be taken into account as well as stakeholders interests. For bivalve aquaculture it means that attention is given to both positive and negative feedbacks to the ecosystem. In general, in the literature and in management approaches, attention has focused on avoiding adverse effects; the large potential of bivalve aquaculture for providing ecosystem services is generally underestimated. It is therefore concluded that analyses of ecosystem services and feedback mechanisms that attribute to the ecological carrying capacity need more attention.

2. The approach for bivalve aquaculture carrying capacity follows a hierarchical structure. Social carrying capacity is determined by what stakeholders consider to be acceptable effects of bivalve aquaculture. Hence social CC deals with decision making mechanisms, varying from market to self-organisation. These mechanisms are not different from other decision making processes, but in this case they are based on knowledge about ecological carrying capacity. However, as long as ecological carrying capacity is not established as an intrinsic feature of the ecosystem, and is defined by what society considers acceptable, ecological carrying capacity is part of social carrying capacity.

3. The key issue in bivalve aquaculture carrying capacity is the relation between production and ecological capacity. It requires detailed information on the positive and negative effects of bivalve aquaculture on the ecosystem to evaluate the relation between production and ecological carrying capacity, as well as reference values to establish thresholds and standards. Tools that are available to address this relationship, consist of simple indices to complex models. Applications depend on specific management questions in the respective areas.

4. Management of bivalve aquaculture capacity can make use of standards and threshold values to avoid adverse effects. Given the role of bivalves in the ecosystem including the various feedback types, a more advanced approach is to make use of simulation models that predict the integrated effect of various levels of bivalve aquaculture for specific management goals, such as improved ecosystem resilience. In practice, bivalve aquaculture management is confronted with different competing stocks of cultured, wild, restoration and invasive origin. Scenario models can help in finding the balance between maximizing production capacity and optimizing ecological carrying capacity in areas with bivalve aquaculture.

Acknowledgements The authors are grateful to dr Henrice Jansen and dr Jon Grant for their constructive comments.

\section{Annex I}

Overview of ecosystem characteristics of bivalve culture areas related to indices for carrying capacity estimation (Tables 23.4, 23.5, 23.6 and Fig. 23.6). 


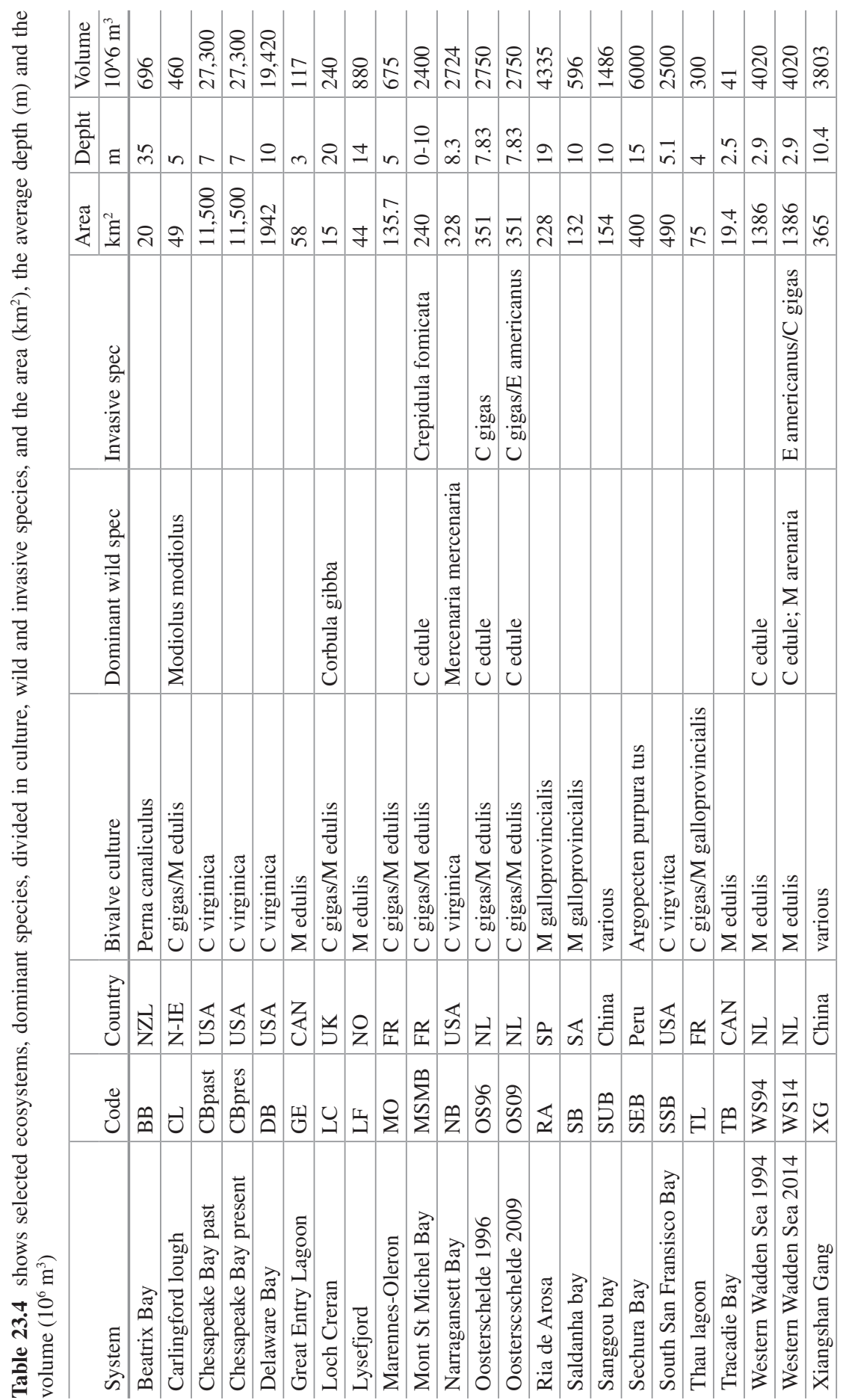




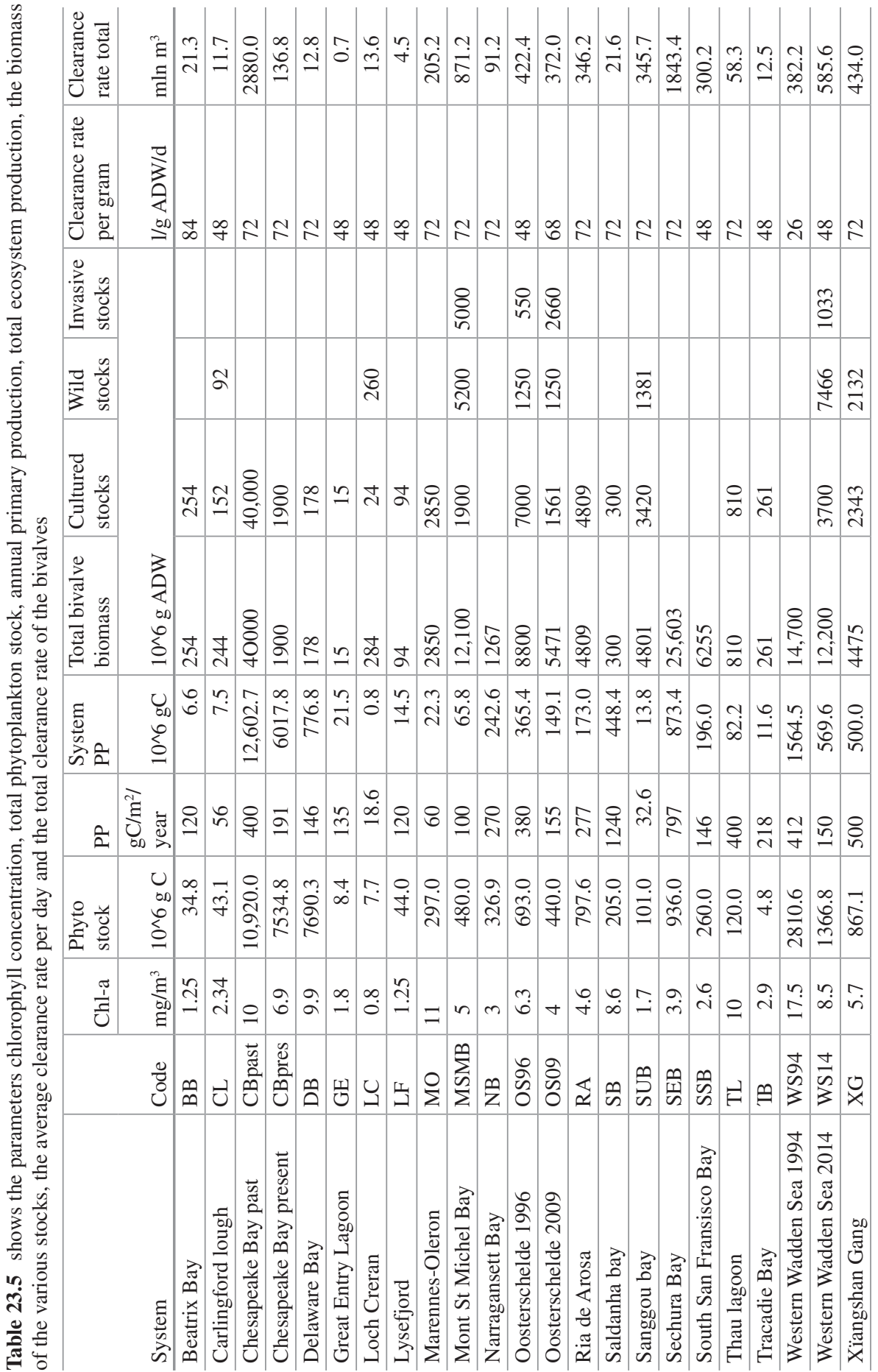




\begin{tabular}{|c|c|c|c|c|c|c|c|c|c|c|c|c|c|c|c|c|c|c|}
\hline & 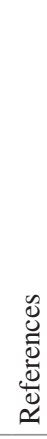 & $\begin{array}{l}\hat{\delta} \\
\stackrel{d}{0} \\
0 \\
0 \\
0 \\
0\end{array}$ & 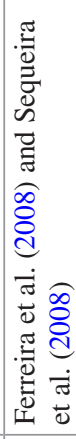 & 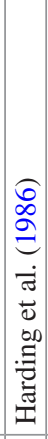 & 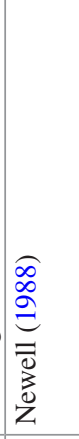 & 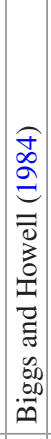 & 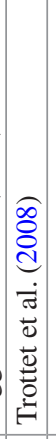 & 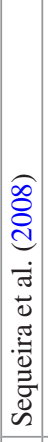 & 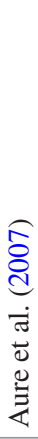 & 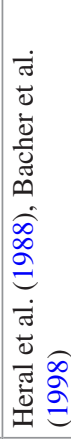 & 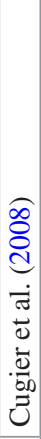 & 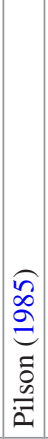 & 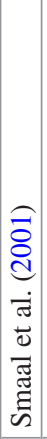 & 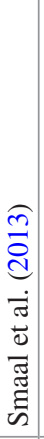 & 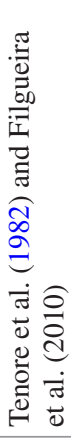 & 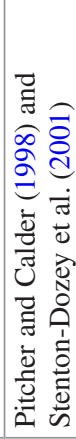 & 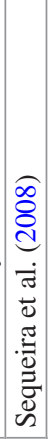 & 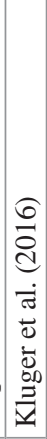 \\
\hline & $\underset{\substack{E \\
0 \\
0}}{E}$ & $\stackrel{2}{0}$ & 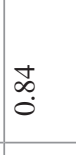 & $\stackrel{t}{0}$ & î & $\frac{\infty}{\stackrel{\infty}{\sim}}$ & $\begin{array}{l}\mathcal{C} \\
\stackrel{i}{u}\end{array} \mid$ & 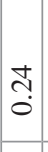 & $\stackrel{\infty}{-}$ & $\begin{array}{l}\sigma \\
0 \\
i\end{array}$ & $\begin{array}{l}\text { I. } \\
\text { i̊ }\end{array}$ & $\stackrel{n}{-}$ & $\stackrel{t}{n}$ & $\stackrel{?}{\stackrel{9}{0}}$ & $\stackrel{m}{\stackrel{0}{0}}$ & $\stackrel{\infty}{\stackrel{\infty}{\sim}}$ & $\begin{array}{l}\stackrel{2}{3} \\
\grave{1}\end{array}$ & $\stackrel{\infty}{+}$ \\
\hline & $\stackrel{\breve{E}}{\stackrel{5}{\mathrm{E}}}$ & $\frac{0}{6}$ & $\begin{array}{l}0 \\
\infty \\
0 \\
0\end{array}$ & $\begin{array}{l}\check{O} \\
\stackrel{0}{0}\end{array}$ & $\begin{array}{l}\infty \\
\\
\stackrel{2}{n} \\
\end{array}$ & $\begin{array}{l}8 \\
\check{x} \\
\tilde{n} \\
-\end{array}$ & $\begin{array}{l}\infty \\
\infty \\
\dot{\gamma} \\
\forall\end{array}$ & $\stackrel{n}{\stackrel{2}{2}}$ & $\begin{array}{c}\stackrel{1}{d} \\
\dot{d}\end{array}$ & 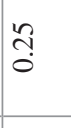 & $\stackrel{\infty}{\tilde{m}}$ & 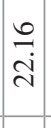 & 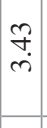 & $\begin{array}{l}\text { ñ } \\
\text { i }\end{array}$ & $\stackrel{i}{i}$ & ฯి & 華 & $\begin{array}{l}\dot{0} \\
\dot{m}\end{array}$ \\
\hline & $\begin{array}{l}\vec{\theta} \\
0 \\
0 \\
0\end{array}$ & $\stackrel{\text { f }}{\circ}$ & ָे & $\hat{n}$ & $\stackrel{\circ}{\circ}$ & $\stackrel{9}{=}$ & $\begin{array}{l}\infty \\
0 \\
0\end{array}$ & \begin{tabular}{l}
$n$ \\
\multirow{2}{n}{} \\
0
\end{tabular} & 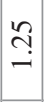 & 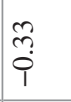 & $\stackrel{\text { f }}{\stackrel{8}{\circ}}$ & ¿ & $\begin{array}{l}2 \\
0 \\
0 \\
1\end{array}$ & $\stackrel{m}{\stackrel{\rho}{\varphi}}$ & 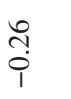 & 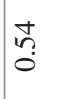 & 古 & $\bar{?}$ \\
\hline & $\stackrel{\underline{\underline{E}}}{\stackrel{E}{E}}$ & $\stackrel{\sqrt[n]{n}}{i}$ & @ & $\stackrel{?}{+}$ & ọ. & $\begin{array}{l}\mathbf{v} \\
\stackrel{\sigma}{n}\end{array}$ & in & $\stackrel{0}{\stackrel{0}{-}}$ & 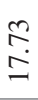 & $\stackrel{0}{+}$ & 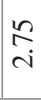 & $\stackrel{n}{=}$ & $\begin{array}{l}0 \\
0 \\
0\end{array}$ & $\frac{\infty}{0}$ & in & $\stackrel{?}{\stackrel{n}{r}}$ & $\begin{array}{l}\hat{\infty} \\
i \\
i\end{array}$ & 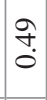 \\
\hline & ס & $\begin{array}{c}\tilde{\sigma} \\
\text { i } \\
\text { ñ. }\end{array}$ & 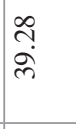 & 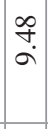 & $\begin{array}{l}\stackrel{0}{2} \\
2 \\
2\end{array}$ & 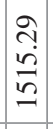 & $\begin{array}{l}0 \\
n \\
i \\
0 \\
-1\end{array}$ & $\begin{array}{l}\overline{6} \\
\overline{-} \\
-\end{array}$ & $\begin{array}{l}\dot{0} \\
\dot{n} \\
2\end{array}$ & ते & 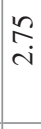 & $\begin{array}{l}0 \\
\infty \\
2 \\
2\end{array}$ & 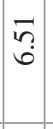 & ले & 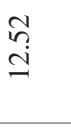 & $\frac{\hat{n}}{\stackrel{n}{N}}$ & 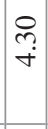 & $\stackrel{2}{n}$ \\
\hline & ס & خे & $\stackrel{m}{i}$ & $\begin{array}{l}\infty \\
\infty \\
\dot{0}\end{array}$ & $\stackrel{\sim}{\stackrel{n}{c}}$ & $\begin{array}{l}\curvearrowright \\
\swarrow \\
\alpha\end{array}$ & $\begin{array}{l}\tilde{m} \\
0\end{array}$ & $\begin{array}{l}0 \\
0 \\
0\end{array}$ & $\begin{array}{c}\dot{D} \\
\dot{m}\end{array}$ & $\vec{m}$ & 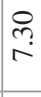 & $\stackrel{\sim}{\dddot{m}}$ & $\stackrel{8}{\stackrel{-}{-}}$ & $\stackrel{\varkappa}{\varkappa}$ & $\begin{array}{l}\bar{\sigma} \\
\dot{+}\end{array}$ & $\stackrel{0}{+}$ & $\underset{n}{n}$ & $\stackrel{\hat{\sigma}}{.}$ \\
\hline & ס & 2 & ๙ & ป & ป & à & 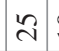 & 잉 & $=$ & $\overparen{r}$ & - & i & q & ஓ & $\widehat{ત}$ & $\infty$ & $\because$ & o. \\
\hline & $\begin{array}{l}8 \\
0\end{array}$ & $\stackrel{\oplus}{\oplus}$ & $\vec{U}$ & 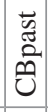 & 岂 & ๑ै & 突 & U, & 岌 & $\stackrel{O}{\Sigma}$ & $\sum_{\sum}^{n}$ & $\frac{n}{z}$ & 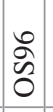 & $\begin{array}{l}\stackrel{8}{ } \\
\text { రి }\end{array}$ & 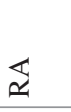 & $\approx$ & 点 & 党 \\
\hline & 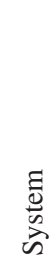 & 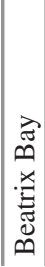 & 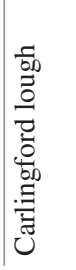 & 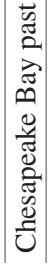 & 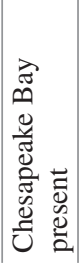 & 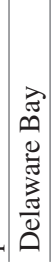 & 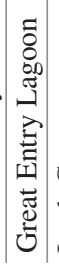 & 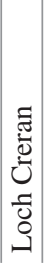 & 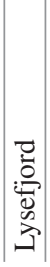 & 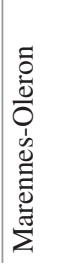 & 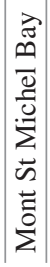 & 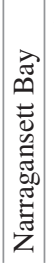 & $\mid \begin{array}{l}0 \\
2 \\
2 \\
0 \\
\frac{0}{2} \\
\frac{0}{0} \\
0 \\
0 \\
\frac{0}{2} \\
0 \\
0\end{array}$ & 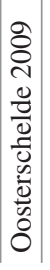 & 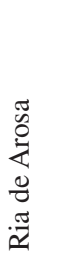 & 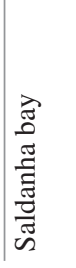 & 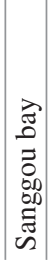 & 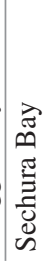 \\
\hline
\end{tabular}




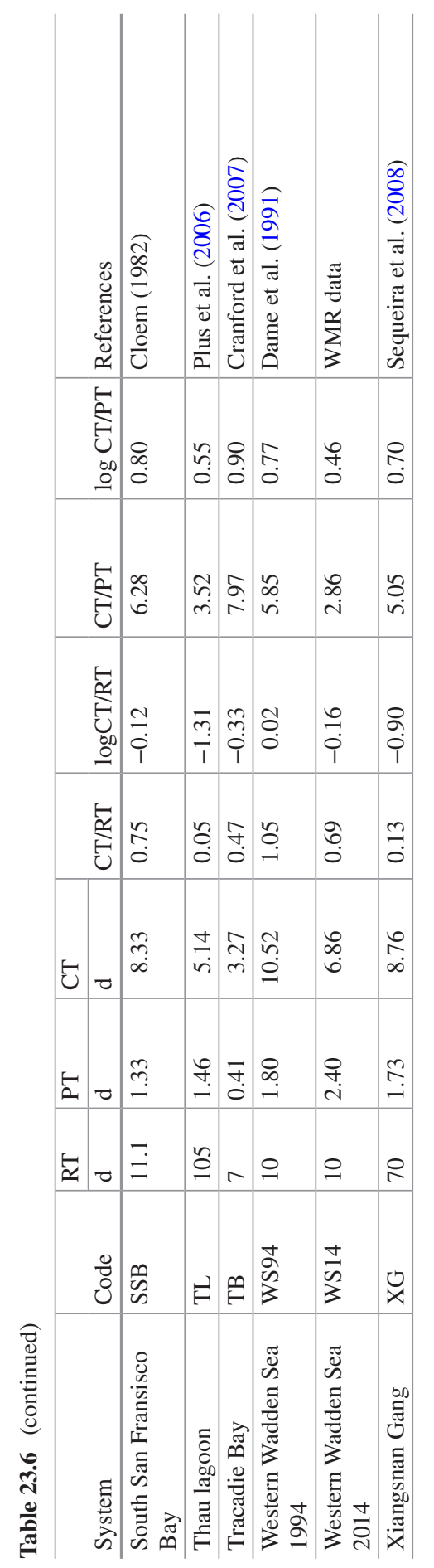




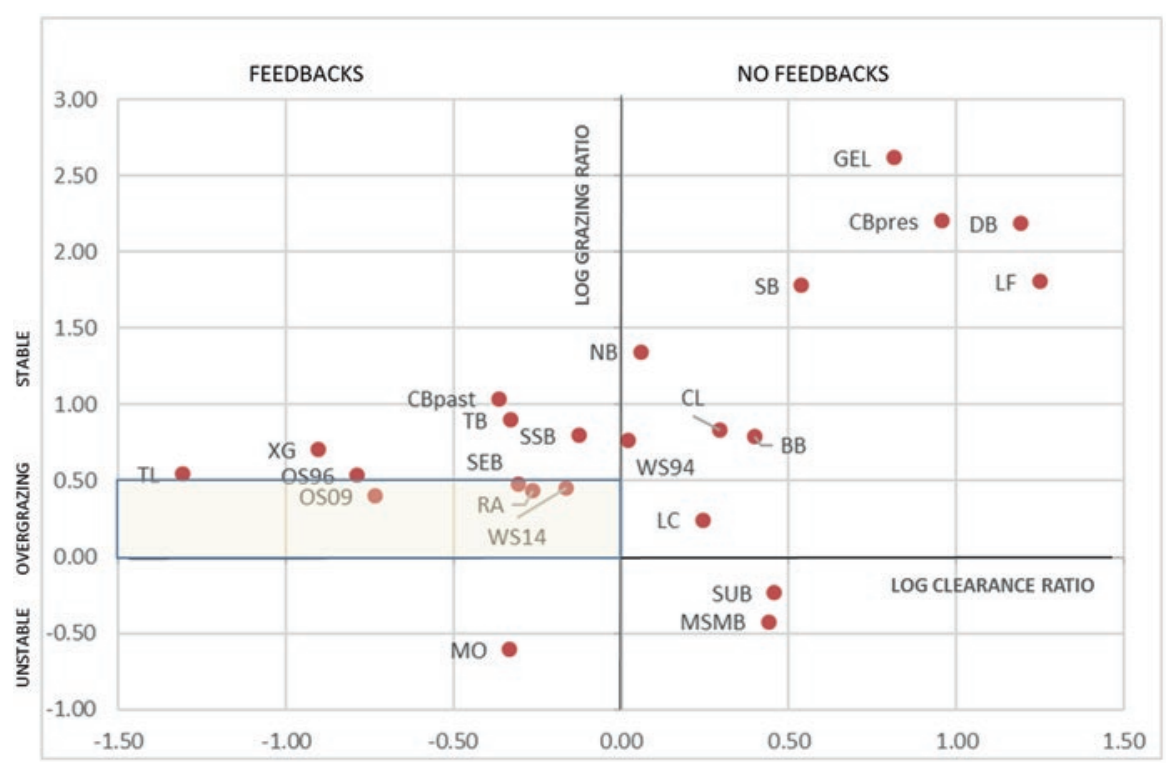

Fig. 23.6 Log Grazing Ratio as a function of Log Clearance Ratio with the right panel showing the areas with a shorter residence time than clearance time, hence less regulation or feedbacks by the bivalves on the ecosystem. The left panel shows the areas where the bivalves potentially have significant feedback effects to ecosystem processes. The index also shows a risk of overgrazing at Log GR values $<0.5$. This seems to be the case for Wadden Sea 2014, Ria de Arosa and Oosterschelde 2009. As mentioned previously, the bivalves in Marennes-Oleron (MO) rely on microphytobenthos rather than phytoplankton; in Sungo Bay (SUB) and Mt. Saint Michel Bay (MSMB) the grazing ratio is low but the residence time is so short that bivalves rely on food import rather than local production, as $\log \mathrm{CR}>0$

\section{References}

Aguera A, van de Koppel J, Jansen JM, Smaal AC, Bouma TJ (2015) Beyond food: a foundation species facilitates its own predator. Oikos 124:1-7

Aure J, Strohmeier T, Strand Ø (2007) Modelling current speed and carrying capacity in long-line blue mussel (Mytilus edulis) farms. Aquac Res 38:304-312

Bacher C, Duarte P, Ferreira JG, Héral M, Raillard O (1998) Assessment and comparison of the Marennes-Oléron Bay (France) and Carlingford Lough (Ireland) carrying capacity with ecosystem models. Aquat Ecol 31:379-394

Bacher C et al (2019) Spatial, ecological and social dimensions of assessments for bivalve farming management. In: Smaal A, Ferreira JG, Grant J, Petersen JK, Strand O (eds) Goods and services of marine bivalves. Springer, Cham, pp 527-549

Barnes TK, Volety AK, Chartier K, Mazzotti FJ, Pearlstine I (2007) A habitat suitability index model for the eastern oyster (Crassostrea virginica), a tool for restoration of the $\mathrm{C}$ aloosahatchee estuary, Florida. J Shellfish Res 26(4):949-959

Biggs RB, Howell BA (1984) The estuary as a sediment trap: alternate approaches to estimating filter efficiencies. In: Kennedy VS (ed) The estuary as a filter. Academic, New York, pp 107-129

Byron C, Bengtson D, Costa-Pierce B, Calanni J (2011a) Integrating science into management: ecological carrying capacity of bivalve shellfish aquaculture. Mar Policy 35:363-370 
Byron C, Link J, Costa-Pierce B, Bengtson D (2011b) Calculating ecological carrying capacity of shellfish aquaculture using mass-balance modelling: Narragansett Bay, Rhode Island. Ecol Model 222:1743-1755

Byron CJ, Jin D, Dalton TM (2015) An integrated ecological-economic modeling framework for the sustainable management of oyster farming. Aquaculture 447:15-22

Cloern JE (1982) Does the benthos control phytoplankton biomass in south San Francisco Bay? Mar Ecol Prog Ser 9:191-202

Craeymeersch J, Jansen H (2019) Bivalve assemblages as hotspots for biodiversity. In: Smaal A, Ferreira JG, Grant J, Petersen JK, Strand O (eds) Goods and services of marine bivalves. Springer, Cham, pp 275-294

Cranford PJ, Strain PM, Dowd M, Hargrave BT, Grant J, Archambault MC (2007) Influence of mussel aquaculture on nitrogen dynamics in a nutrient enriched coastal embayment. Mar Ecol Prog Ser 347:61-78

Cranford PJ, Hargrave B, Li W (2009) No mussel is an island. ICES Insight 46:44-49

Cranford PJ, Kamermans P, Krause G, Mazurié J, Buck BH, Dolmer P, Fraser D, Van Nieuwenhove K, O’Beirn FX, Sanchez-Mata A, Thorarinsdótir GG, Strand Ø (2012) An ecosystem-based approach and management framework for the integrated evaluation of bivalve aquaculture impacts. Aquac Environ Interact 2:193-213

Cugier P, Struski C, Blanchard M, Mazurie J, Pouvreau J, Óliver F (2008) Studying the carrying capacity of Mont Saint Michel Bay (France): respective role of the main filter feeders communities, ICES online at www.ices.dk/products/CMdocs/CM-2008/H/H0108.pdf. Nov 2010

Dame RF (1996) Ecology of marine bivalves: an ecosystem approach. CRC Mar Sci Ser 272 pp

Dame RF, Prins TC (1998) Bivalve carrying capacity in coastal ecosystems. Aquat Ecol 31:409-421

Dame R, Dankers N, Prins T, Jongsma H, Smaal A (1991) The influence of mussel beds on nutrients in the Western Wadden Sea and Eastern Scheldt Estuaries. Estuaries 14:130-138

Dowd M (2005) A bio-physical coastal ecosystem model for assessing environmental effects of marine bivalve aquaculture. Ecol Model 183:323-346

European Union, 2017. Regulation (EU) No 1143/2014 of the European Parliament and of the Council of 22 October 2014 on the prevention and management of the introduction and spread of invasive alien species

Ferreira JG, AJS H, Monteiro P, Moore H, Service M, Pascoe PL, Ramos L, Sequeira A (2008) Integrated assessment of ecosystem-scale carrying capacity in shellfish growing areas. Aquaculture 275:138-151

Ferreira JG et al (2019) Assessment of nutrient trading services from bivalve farming. In: Smaal A, Ferreira JG, Grant J, Petersen JK, Strand O (eds) Goods and services of marine bivalves. Springer, Cham, pp 551-584

Filgueira R, Comeau LA, Guyondet T, McKindsey CW, Byron CJ (2015) Modelling carrying capacity of bivalve aquaculture: a review of definitions and methods. Encyclopedia of sustainability science and technology. Springer, New York

Gibbs MT (2007) Sustainability performance indicators for suspended bivalve aquaculture activities. Ecol Indic 7:94-107

Gibbs MT (2009) Implementation barriers to establishing a sustainable coastal aquaculture sector. Mar Policy 33:83-89

Grant J, Pastres R (2019) Ecosystem models of bivalve aquaculture: implications for supporting goods and services. In: Smaal A, Ferreira JG, Grant J, Petersen JK, Strand O (eds) Goods and services of marine bivalves. Springer, Cham, pp 507-525

Grant J, Curran KJ, Guyondet TL, Tita G, Bacher C, Koutitonsky V, Dowd M (2007) A box model of carrying capacity for suspended mussel aquaculture in Lagune de la Grande-Entrée, Iles-dela-Madeleine, Québec. Ecol Model 200:193-206

Harding LW, Meeson BW, Fisher TR (1986) Phytoplankton production in two east coast estuaries: photosynthesis light functions and patterns of carbon assimilation in Chesapeake and Delaware Bays. Est Coast Shelf Sci 23:773-806 
Hargreaves JA (2011) Molluscan shellfish aquaculture and best practices management. In: Shumway SE (ed) Shellfish aquaculture and the environment. Wiley-Blackwell, Ames, pp 51-80

Héral M, Deslous-Paoli J-M, Prou J (1988) Approche de la capacité trophique d'un écosystème conchilicole. J Cons Int Explor Mer, Cm 1988/K 22 p

Herman PMJ, Scholten H (1990) Can suspension-feeders stabilize estuarine ecosystems? In: Barnes M, Gibson RN (eds) Trophic relationships in the marine environment. Proceedings of the 24th European marine biology symposium. Aberdeen. University Press, Aberdeen, pp 104-116

Inglis GJ, Hayden BJ, Ross AH (2000) An overview of factors affecting the carrying capacity of coastal embayments for mussel culture. NIWA, Christchurch. Client Report CHC00/69: vi + $31 \mathrm{p}$

Jansen Henrice M, Strand Ø, van Broekhoven W, Strohmeier T, Verdegem MC, Smaal AC (2019) Feedbacks from filter feeders: review on the role of mussels in cycling and storage of nutrients in oligo- meso- and eutrophic cultivation areas. In: Smaal A, Ferreira JG, Grant J, Petersen JK, Strand O (eds) Goods and services of marine bivalves. Springer, Cham, pp 143-177

Kamermans P, Capelle J (2019) Provisioning of mussel seed and its efficient use in culture. In: Smaal A, Ferreira JG, Grant J, Petersen JK, Strand O (eds) Goods and services of marine bivalves. Springer, Cham, pp 27-49

Kashiwai M (1995) History of carrying capacity concept as an index of ecosystem productivity (Review). Bull Hokkaido Natl Fish Res Inst 59:81-101

Kluger LC, Taylor MH, Mendo J, Tam J, Wolff M (2016a) Carrying capacity simulations as a tool for ecosystem-based management of a scallop aquaculture system. Ecol Model 331:44-55

Kluger LC, Taylor MH, Rivera EB, Silva ET, Wolff M (2016b) Assessing the ecosystem impact of scallop bottom culture through a community analysis and trophic modelling approach. MEPS 547:121-135

Kluger LC, Filgueira R, Wolff M (2017) Integrating the concept of resilience into an ecosystem approach to bivalve aquaculture management. Ecosystems. https://doi.org/10.1007/ s10021-017-0118-z

Lawson SR, Manning RE, Valliere WA, Wang B (2003) Proactive monitoring and adaptive management of social carrying capacity in Arches National Park: an application of computer simulation modeling. J Environ Manag 68(3):305-313

McKindsey CW (2013) Carrying capacity for sustainable bivalve aquaculture. In: Christou P, Savin R, Costa-Pierce B, Misztal I, Whitelaw B (eds) Sustainable food production. Springer, New York, pp 449-466. https://doi.org/10.1007/978-1-4614-5797-8

McKindsey CW, Thetmeyer H, Landry T, Silvert W (2006) Review of recent carrying capacity models for bivalve culture and recommendations for research and management. Aquaculture 261(2):451-462

McKindsey CW, Archambault P, Callier MD, Olivier F (2011) Influence of suspended and offbottom mussel culture on the sea bottom and benthic habitats: a review. Can J Zool 89:622-646

Newell RIE (1988) Ecological changes in Chesapeake Bay: are they the result of overharvesting the American oyster, Crassostrea virginica? Understanding the estuary: advances in Chesapeake Bay Research. Chesapeake Research Consortium Publication, Baltimore

Newell RIE (2004) Ecosystem influences of natural and cultivated populations of suspensionfeeding bivalve molluscs: a review. J Shellfish Res 23:51-61

Newell CR, Brady D, Richardson J (2019) Farm-scale production models. In: Smaal A, Ferreira JG, Grant J, Petersen JK, Strand O (eds) Goods and services of marine bivalves. Springer, Cham, pp 485-506

Nobre AM (2009) An Ecological and Economic Assessment Methodology for Coastal Ecosystem Management. Environ Manag 44:185-204

Odum EP (1953) Fundamentals of ecology. Saunders, Philadelphia. pp 574

Ostrom E (2009) A general framework for analyzing sustainability of social-ecological systems. Science 325:419-422 
Passarelli C, Olivier F, Paterson DM, Meziane T, Hubas C (2014) Organisms as cooperative ecosystem engineers in intertidal flats. J Sea Res 92:92-101

Petersen JK, Maar M, Ysebaert T, Herman PMJ (2013) Near-bed gradients in particles and nutrients above a mussel bed in the Limfjorden: influence of physical mixing and mussel filtration. MEPS 490:137-146

Pilson MQ (1985) On the residence time of water in Narragansett Bay. Estuaries 8:2-14

Pitcher GC, Calder D (1998) Shellfish mariculture in the Benguela system: phytoplankton and the availability of food for commercial mussel farms in Saldanha Bay, South Africa. J Shellfish Res 17:15-24

Plus M, La Jeunesse I, Bouraoui F, Zaldivar JM, Chapelle A, Lazure P (2006) Modelling water discharges and nitrogen inputs into a Mediterranean lagoon - impact on the primary production. Ecol Model 193:69-89

Prins TC, Smaal AC, Dame RF (1998) A review of the feedbacks between bivalve grazing and ecosystem processes. Aquat Ecol 31:349-359

Ruesink JL, Lenihan HS, Trimble AC, Heiman KW, Micheli F, Byers JE, Kay MC (2005) Introduction of non-native oysters: ecosystem effects and restoration implications. Annu Rev Ecol Syst 36:643-689

Sequeira A, Ferreira JG, Hawkins AJS, Nobre A, Lourenco P, Zhang XL, Yan X, Nickell T (2008) Trade-offs between shellfish aquaculture and benthic biodiversity: a modelling approach for sustainable management. Aquaculture 274:313-328

Smaal AC, Prins TC (1993) The uptake of organic matter and the release of inorganic nutrients by bivalve suspension feeder beds. In: Dame RF (ed) Bivalve filter feeders in estuarine and coastal ecosystem processes. Springer, Berlin, pp 271-298

Smaal AC, Prins TC, Dankers N, Ball B (1998) Minimum requirements for modelling bivalve carrying capacity. Aquat Ecol 31:423-428

Smaal A, van Stralen M, Schuiling E (2001) The interaction between shellfish culture and ecosystem processes. Can J Fish Aquat Sci 58:991-1002

Smaal AC, Schellekens T, van Stralen MR, Kromkamp JC (2013) Decrease of the carrying capacity of the Oosterschelde estuary (SW Delta, NL) for bivalve filter feeders due to overgrazing? Aquaculture 404-405:28-34

Soto D, Aguilar-Manjarrez J, Brugère C, Angel D, Bailey C, Black K, Edwards P, Costa-Pierce B, Chopin T, Deudero S, Freeman S, Hambrey J, Hishamunda N, Knowler D, Silvert W, Marba N, Mathe S, Norambuena R, Simard F, Tett P, Troell M, Wainberg A (2008) Applying an ecosystem based approach to aquaculture: principles, scales and some management measures. In: Soto D, Aguilar-Manjarrez J, Hishamunda N (eds) Building an ecosystem approach to aquaculture. FAO/Universitat de les Illes Balears Expert Workshop. 7-11 May 2007, Palma de Mallorca, Spain, FAO fisheries and aquaculture proceedings no 14. Rome, FAO, pp 15-35

Stenton-Dozey J, Probyn T, Busby A (2001) Impact of mussel (Mytilus galloprovincialis) raft culture on benthic macrofauna, in situ oxygen uptake, and nutrient fluxes in Saldanha Bay, South Africa. Can J Fish Aquat 58:1021-1031

Tarrant MA, English DBK (1996) A crowding-based model of social carrying capacity: applications for white-water boating use. J Leis Res 28(3):155-168

Tenore KR, Boyer LF, Cal RM, Corral J, Garcia-Fernandez C, Gonzalez N, Gonzalez-Gurriaran E, Hanson RB, Iglesias J, Krom M, Lopez-Jamar E, McClain J, Pamatmat MM, Perez A, Rhoads DC, de Santiago G, Tietjen J, Westrich J, Windom HL (1982) Coastal upwelling in the Rias Bajas, NW Spain: contrasting the benthic regimes of the Rias de Arosa and de Muros. J Mar Res 40:701-772

Tett P, Portilla E, Gillibrand P, Inall M (2011) Carrying and assimilative capacities: the ACExRLESV model for sea-loch aquaculture. Aquac Res 42:51-67

Thompson JK (2005) One estuary, one invasion, two responses: phytoplankton and benthic community dynamics determine the effect of an estuarine invasive suspension feeder. In: Dame RF, Olenin S (eds) The comparative roles of suspension feeders in ecosystems, Nato science series IV, vol 47, pp 291-316 
Trottet A, Roy S, Tamigneaux E, Lovejoy C, Tremblay R (2008) Influence of suspended mussel farming on planktonic communities in Grande-Entrée Lagoon, Magdalen Islands (Québec, Can- ada). Aquaculture 276:91-102

Walker B, Carpenter S, Anderies J, Abel N, Cumming G, Janssen M, Lebel L, Norberg J, Peterson GD, Pritchard R (2003) Resilience management in social-ecological systems: a working hypothesis for a participatory approach. Conserv Ecol 6:1-14

WWF (2010) Bivalve aquaculture dialogue standards. www.worldwildlife.org/what/globalmarkets/aquaculture/WWFBinaryitem17872.pdf

Ysebaert T, Walles B, Haner J, Hancock B (2019) Habitat modification and coastal protection by ecosystem-engineering reef-building bivalves. In: Smaal A, Ferreira JG, Grant J, Petersen JK, Strand O (eds) Goods and services of marine bivalves. Springer, Cham, pp 253-273

Zeldis J (2005) Magnitudes of natural and mussel farm-derived fluxes of carbon and nitrogen in the Firth of Thames, NIWA Client Report: CHC2005-048

Open Access This chapter is licensed under the terms of the Creative Commons Attribution 4.0 International License (http://creativecommons.org/licenses/by/4.0/), which permits use, sharing, adaptation, distribution and reproduction in any medium or format, as long as you give appropriate credit to the original author(s) and the source, provide a link to the Creative Commons license and indicate if changes were made.

The images or other third party material in this chapter are included in the chapter's Creative Commons license, unless indicated otherwise in a credit line to the material. If material is not included in the chapter's Creative Commons license and your intended use is not permitted by statutory regulation or exceeds the permitted use, you will need to obtain permission directly from the copyright holder. 